Jolanta Bucińska

\title{
Zgodność z Konstytucją RP niektórych przepisów ustawy o Instytucie Pamięci Narodowej - Komisji Ścigania Zbrodni przeciwko Narodowi Polskiemu - wniosek Prezydenta RP do TK (sygn. akt K 1/18) ${ }^{1}$
}

\begin{abstract}
Conformity to the Constitution of the Republic of Poland of certain rules of the Act on the Institute of National Remembrance - Commission for the Prosecution of Crimes against the Polish Nation - application of the President of the Republic (ref. no. K 1/18): The author of the draft position claims that the rules in question - regarding the phrases "Ukrainian nationalists" and "Eastern Małopolska" conform to the Constitution. Article 55a para. 1, which set outs sanctions of fine or imprisonment for up to 3 years, imposed to anyone who attributing, publicly and contrary to facts, the responsibility or coresponsibility to the Polish Nation or to the Polish State for Nazi crimes committed by the Third German Reich or for other offenses constituting crimes against peace, humanity or war crimes, or in a different way grossly reduces the responsibility of the actual perpetrators of these crimes, conforms to the the Constitution. Moreover, the above-mentioned sanctions do not violate the principle of proportionality.
\end{abstract}

Keywords: Institute of National Remembrance, Constitutional Tribunal

Słowa kluczowe: Instytut Pamięci Narodowej, Trybunał Konstytucyjny

Doktor nauk prawnych, ekspert ds. legislacji BAS; jolanta.bucinska@sejm.gov.pl.

Na podstawie art. 69 ust. 2 w związku z art. 42 pkt 3 ustawy z dnia 30 listopada 2016 r. o organizacji i trybie postępowania przed Trybunałem Konstytucyjnym (Dz. U. poz. 2072), w imieniu Sejmu Rzeczypospolitej Polskiej przedkładam wyjaśnienia w sprawie wniosku Prezydenta Rzeczypospolitej Polskiej z 14 lutego 2018 r. (sygn. akt K 1/18), jednocześnie wnosząc o uznanie, że:

1) art. 1 pkt 1 lit. a tiret trzecie ustawy z dnia 18 grudnia 1998 r. o Instytucie Pamięci Narodowej - Komisji Ścigania Zbrodni przeciwko Narodowi Polskiemu (Dz.U. 2016, poz. 1575, oraz 2018, poz. 5, ze zm.) w części obejmującej

1 Projekt stanowiska sporządzony 14 marca 2018 r., sygn. akt K 1/18; BAS-WAKU $363 / 18$. 
wyrazy „ukraińskich nacjonalistów” jest zgodny z art. 42 ust. 1 w związku $\mathrm{z}$ art. 2 oraz art. 31 ust. 3 Konstytucji;

2) art. 2a ustawy wymienionej w pkt 1 w części obejmującej wyrazy „ukraińskich nacjonalistów” oraz wyrazy „Małopolski Wschodniej” jest zgodny z art. 42 ust. $1 \mathrm{w}$ związku $\mathrm{z}$ art. 2 oraz art. 31 ust. 3 Konstytucji;

3) art. 55a ustawy wymienionej w pkt 1 jest zgodny $\mathrm{z}$ art. 42 ust. $1 \mathrm{w}$ związku $\mathrm{z}$ art. 2 i art. 31 ust. 3, a także $\mathrm{z}$ art. 54 ust. $1 \mathrm{w}$ związku z art. 31 ust. 3 Konstytucji.

\section{Uzasadnienie}

\section{Przedmiot kontroli}

1. Postępowanie przed Trybunałem Konstytucyjnym zostało wszczęte przez Prezydenta Rzeczypospolitej Polskiej (dalej: wnioskodawca) wnioskiem z 14 lutego 2018 r. (sygn. akt K 1/18), w którego petitum wnioskodawca wniósł „o zbadanie zgodności z Konstytucją ustawy z dnia 26 stycznia 2018 r. o zmianie ustawy o Instytucie Pamięci Narodowej - Komisji Ścigania Zbrodni przeciwko Narodowi Polskiemu, ustawy o grobach i cmentarzach wojennych, ustawy o muzeach oraz ustawy o odpowiedzialności podmiotów zbiorowych za czyny zabronione pod groźbą kary (Dz. U. poz. 369)”. Wnioskodawca sformułował swoje żądanie w sposób następujący: „Ustawie tej zarzucam niezgodność:

1) art. $55 \mathrm{a} \mathrm{z}$ art. 2 oraz art. 42 ust. $1 \mathrm{w}$ związku $\mathrm{z}$ art. 31 ust. 3 oraz art. 54 ust. 1 w związku z art. 31 ust. 3 Konstytucji;

2) art. 1 pkt 1 lit. a tiret trzecie w części obejmującej wyrazy «ukraińskich nacjonalistów i» oraz art. 2a w części obejmującej wyrazy «ukraińskich nacjonalistów» oraz wyrazy «i Małopolski Wschodniej» z art. 2 oraz art. 42 ust. 1 w związku z art. 31 ust. 3 Konstytucji”.

W czasie występowania przez wnioskodawcę z pismem inicjującym postępowanie w rozpatrywanej sprawie przepisy ustawy z dnia 26 stycznia $2018 \mathrm{r}$. o zmianie ustawy o Instytucie Pamięci Narodowej - Komisji Ścigania Zbrodni przeciwko Narodowi Polskiemu, ustawy o grobach i cmentarzach wojennych, ustawy o muzeach oraz ustawy o odpowiedzialności podmiotów zbiorowych za czyny zabronione pod groźbą kary (Dz. U. poz. 369; dalej: ustawa nowelizująca) znajdowały się w okresie vacatio legis. Z uzasadnienia wniosku jednoznacznie wynika, że sformułowane przez wnioskodawcę zarzuty dotyczą konstytucyjności przepisów znowelizowanych, a nie przepisów nowelizujących. Z tego względu Sejm przyjął, że właściwym przedmiotem kontroli w niniejszej sprawie są art. 1 pkt 1 lit. a, art. 2a oraz art. 55a ustawy z dnia 18 grudnia 1998 r. o Instytucie Pamięci Narodowej - Komisji Ścigania Zbrodni przeciwko Narodowi Polskiemu (Dz.U. 2016, poz. 1575, ze zm.; dalej: ustawa o IPN), zamiast odpowiednich 
przepisów ustawy nowelizującej, które zmieniają brzmienie bądź wprowadzają przepisy do ustawy o IPN, co do treści których wnioskodawca ma zastrzeżenia. Nie ma przy tym potrzeby dookreślania, że zaskarżone przepisy ustawy o IPN są badane w brzmieniu nadanym odpowiednio przez art. 1 pkt 1 lit. a, pkt 2 oraz pkt 6 ustawy nowelizującej, gdyż jest to obecnie obowiązujące brzmienie zaskarżonych przepisów.

2. Zakwestionowane przepisy mają następujące brzmienie:

Zgodnie $\mathrm{z}$ art. 1 pkt 1 lit. a ustawy o IPN:

„Ustawa reguluje:

1) ewidencjonowanie, gromadzenie, przechowywanie, opracowywanie, zabezpieczenie, udostępnianie i publikowanie dokumentów organów bezpieczeństwa państwa, wytworzonych oraz gromadzonych od dnia 22 lipca 1944 r. do dnia 31 lipca 1990 r., a także organów bezpieczeństwa Trzeciej Rzeszy Niemieckiej i Związku Socjalistycznych Republik Radzieckich, dotyczących:

a) popełnionych na osobach narodowości polskiej lub obywatelach polskich innych narodowości w okresie od dnia 8 listopada 1917 r. do dnia 31 lipca 1990 r.:

- zbrodni nazistowskich,

- zbrodni komunistycznych,

- zbrodni ukraińskich nacjonalistów i członków ukraińskich formacji kolaborujących z Trzecią Rzeszą Niemiecką,

- innych przestępstw stanowiących zbrodnie przeciwko pokojowi, ludzkości lub zbrodnie wojenne".

Zgodnie z art. 2a ustawy o IPN: „Zbrodniami ukraińskich nacjonalistów i członków ukraińskich formacji kolaborujących z Trzecią Rzeszą Niemiecką, w rozumieniu ustawy, są czyny popełnione przez ukraińskich nacjonalistów w latach 1925-1950, polegające na stosowaniu przemocy, terroru lub innych form naruszania praw człowieka wobec jednostek lub grup ludności. Zbrodnią ukraińskich nacjonalistów i członków ukraińskich formacji kolaborujących z Trzecią Rzeszą Niemiecką jest również udział w eksterminacji ludności żydowskiej oraz ludobójstwie na obywatelach II Rzeczypospolitej na terenach Wołynia i Małopolski Wschodniej”.

Natomiast, zgodnie $\mathrm{z}$ art. 55a ustawy o IPN:

„1. Kto publicznie i wbrew faktom przypisuje Narodowi Polskiemu lub Państwu Polskiemu odpowiedzialność lub współodpowiedzialność za popełnione przez III Rzeszę Niemiecką zbrodnie nazistowskie określone w art. 6 Karty Międzynarodowego Trybunału Wojskowego załączonej do Porozumienia międzynarodowego $\mathrm{w}$ przedmiocie ścigania i karania głównych przestępców wojennych Osi Europejskiej, podpisanego w Londynie dnia 8 sierpnia 1945 r. (Dz. U. z 1947 r. poz. 367), lub za inne przestępstwa stanowiące zbrodnie przeciwko pokojowi, ludzkości lub zbrodnie wojenne lub w inny sposób rażąco pomniejsza odpowiedzialność rzeczywistych sprawców tych zbrodni, podlega grzywnie lub karze pozbawienia wolności do lat 3. Wyrok jest podawany do publicznej wiadomości. 
2. Jeżeli sprawca czynu określonego $\mathrm{w}$ ust. 1 działa nieumyślnie, podlega grzywnie lub karze ograniczenia wolności.

3. Nie popełnia przestępstwa sprawca czynu zabronionego określonego w ust. 1 i 2, jeżeli dopuścił się tego czynu w ramach działalności artystycznej lub naukowej".

3. Jak zaznaczono wyżej, kwestionowane przepisy zostały uchwalone przez Sejm ustawą nowelizującą wprowadzającą zmiany w ustawie o IPN.

Zmiana przewidziana $\mathrm{w}$ art. 1 ustawy o IPN (wprowadzona na podstawie art. 1 pkt 1 lit. a ustawy nowelizującej) przewiduje rozszerzenie zakresu ustawy o zbrodnie „ukraińskich nacjonalistów i członków ukraińskich formacji kolaborujących z Trzecią Rzeszą Niemiecką", a tym samym poszerza zakres odpowiedzialności za przestępstwo określone w art. 55 ustawy o IPN, zgodnie z którym, „[k] to publicznie i wbrew faktom zaprzecza zbrodniom, o których mowa w art. 1 pkt 1, podlega grzywnie lub karze pozbawienia wolności do lat 3".

Zbrodnie te zostały zdefiniowane $\mathrm{w}$ art. 2a ustawy o IPN (dodanym przez art. 1 pkt 2 ustawy nowelizującej).

Ponadto ustawa nowelizująca wprowadza w dodanym art. 55a ustawy o IPN nowy typ przestępstwa, którym jest publiczne i wbrew faktom przypisywanie Narodowi Polskiemu lub Państwu Polskiemu odpowiedzialności lub współodpowiedzialności za popełnione przez III Rzeszę Niemiecką zbrodnie nazistowskie określone w art. 6 Karty Międzynarodowego Trybunału Wojskowego lub za inne przestępstwa stanowiące zbrodnie przeciwko pokojowi, ludzkości lub zbrodnie wojenne lub w inny sposób rażąco pomniejsza odpowiedzialność rzeczywistych sprawców tych zbrodni (art. 1 pkt 6 ustawy nowelizującej).

\section{Zarzuty wnioskodawcy}

1. Wnioskodawca $\mathrm{w}$ pierwszej kolejności wnosi o stwierdzenie niezgodności art. 55a ustawy o IPN z art. 2 oraz art. 42 ust. 1 w związku z art. 31 ust. 3 Konstytucji ze względu na to, że przepis ten, penalizując czyny polegające na publicznym i wbrew faktom przypisywaniu Narodowi Polskiemu lub Państwu Polskiemu odpowiedzialności za zbrodnie prawa międzynarodowego oraz za zbrodnie przeciwko pokojowi, ludzkości lub zbrodnie wojenne lub czyny polegające na rażącym pomniejszaniu odpowiedzialności rzeczywistych sprawców tych zbrodni w inny sposób, zawiera jednocześnie zwroty niedookreślone, uniemożliwiające precyzyjne wskazanie znamion czynu karalnego oraz zrekonstruowanie jego kontratypu. W ocenie wnioskodawcy, art. 55a ustawy o IPN narusza tym samym zasadę określoności prawa, wyrażoną $\mathrm{w}$ art. 2 Konstytucji oraz wynikającą z niej szczegółową zasadę określoności czynu zabronionego ujętą w art. 42 ust. 1 Konstytucji (wniosek, s. 11).

Wątpliwości wnioskodawcy budzi także zgodność kwestionowanego przepisu $\mathrm{z}$ art. 42 ust. $1 \mathrm{w}$ związku $\mathrm{z}$ art. 31 ust. Konstytucji w zakresie, $\mathrm{w}$ jakim przepis ten przewiduje karę do 3 lat pozbawienia wolności, ze względu na nieproporcjo- 
nalną ingerencję w sferę praw i wolności jednostki. Ponadto naruszenie art. 31 ust. 3 Konstytucji, zdaniem wnioskodawcy, polega na użyciu w kwestionowanym przepisie pojęć nieostrych, pozwalających na daleko idącą dowolność interpretacyjną (wniosek, s. 12).

2. Wnioskodawca kwestionuje zgodność art. 55a ustawy o IPN z art. 54 ust. 1 w związku z art. 31 ust. 3 Konstytucji, ponieważ w sposób nieproporcjonalny ogranicza swobodę wyrażania poglądów oraz rozpowszechniania informacji. Przedstawione niejasności co do zakresu czynu zabronionego oraz świadomość grożącej sankcji karnej może, zdaniem wnioskodawcy, wywołać skutek w postaci powstrzymywania się od publicznych wypowiedzi lub innych form publicznego przekazu dotyczących popełnionych w okresie II wojny światowej zbrodni (wniosek, s. 16).

3. Kolejny stawiany przez wnioskodawcę zarzut dotyczy art. 1 pkt 1 lit. a tiret trzecie ustawy o IPN w części obejmującej wyrazy „ukraińskich nacjonalistów” oraz art. 2a ustawy o IPN w części obejmującej wyrazy „ukraińskich nacjonalistów” oraz wyrazy „i Małopolski Wschodniej”. Skarżone przepisy, zdaniem wnioskodawcy, naruszają art. 2 oraz art. 42 ust. 1 w związku z art. 31 ust. 3 Konstytucji przez zaniechanie precyzyjnego zdefiniowania pojęcia „ukraińskich nacjonalistów” i „Małopolska Wschodnia”, które mogą prowadzić do swobody w interpretacji typu czynu zabronionego z art. 55 ustawy o IPN, znacznie wykraczającej poza ramy dopuszczalne przez wymóg określoności normy karnoprawnej (wniosek, s. 20).

\section{Analiza formalnoprawna}

Analizę merytoryczną należy poprzedzić uwagami formalnymi zmierzającymi do wyjaśnienia dopuszczalności w niniejszym postępowaniu kontroli zgodności art. 1 pkt 1 lit. a tiret trzecie, art. 2a oraz art. 55a ustawy o IPN ze wskazanymi przez wnioskodawcę wzorcami kontroli. Zgodnie z petitum wniosku, zakwestionowanym regulacjom ustawowym zarzucona została niezgodność z art. 2 i art. 42 ust. 1 Konstytucji. Analiza uzasadnienia pisma procesowego prowadzi do wniosku, że wnioskodawca, przywołując jako wzorzec kontroli art. 2 Konstytucji, wyprowadza z niego zasadę określoności czynu zabronionego jako szczególnej postaci zasady określoności przepisów prawa. Podobnie, poddając kwestionowane przepisy ustawy o IPN ocenie zgodności z art. 42 ust. 1 Konstytucji, wskazuje na naruszenie standardu określoności przepisu karnego (zasada nullum crimen, nulla poena sine lege). Z uwagi na tożsamość zasad wywodzonych z obydwu artykułów Konstytucji nie jest potrzebne badanie zgodności skarżonych przepisów osobno z każdym ze wskazanych wzorców. Trybunał Konstytucyjny w wyroku z 25 maja 2004 r. (sygn. akt SK 44/03) potwierdził programowy dla prawa karnego charakter art. 42 ust. 1 Konstytucji, stwierdzając, że z przepisu tego wynikają bezpośrednie konsekwencje dla wszystkich elementów, które składają się na naturę normy prawa karnego (karalność czynu, odpowiedzialność, wymiar kary, 
przedawnienie karalności itd.), a także strukturę normy prawnej przewidującej odpowiedzialność karną. Przypomnieć należy stanowisko Trybunału Konstytucyjnego, który w wyroku z 9 czerwca 1998 r. (sygn. akt K 28/97) wyraził pogląd, że: „[w] razie zakwestionowania zgodności aktu normatywnego ze standardami demokratycznego państwa prawnego, skonkretyzowanymi i rozwiniętymi w odrębnych postanowieniach ustawy zasadniczej, podstawę kontroli konstytucyjności powinny stanowić przede wszystkim szczegółowe przepisy konstytucyjne. W takich sytuacjach nie ma natomiast potrzeby powoływania - jako podstawy kontroli - zasady demokratycznego państwa prawnego, wyrażonej w art. 2 Konstytucji. Zasada ta pełni wówczas przede wszystkim funkcję wskazówki dla interpretacji wymienionych, szczegółowych przepisów ustawy zasadniczej" (por. także wyrok TK z 9 października 2012 r., sygn. akt P 27/11). Wobec powyższego należy zbadać zgodność art. 1 pkt 1 lit. a tiret trzecie, art. 2a oraz art. 55a ustawy o IPN z art. 42 ust. 1 Konstytucji, natomiast art. 2 Konstytucji powinien być uwzględniony jedynie związkowo, co zostało odpowiednio ujęte w petitum stanowiska.

\section{Wzorce kontroli}

1. Wnioskodawca przywołuje w charakterze wzorca kontroli art. 2 Konstytucji, który stanowi: „Rzeczpospolita Polska jest demokratycznym państwem prawnym, urzeczywistniającym zasady sprawiedliwości społecznej”. Zasada demokratycznego państwa prawnego ma charakter klauzuli generalnej o wielopłaszczyznowej treści i dopiero w procesie jej wykładni judykatura i doktryna wyodrębniły zasady pochodne, które w wypadku kontroli konstytucyjności stanowią samodzielne wzorce kontroli. W rozpatrywanej sprawie wnioskodawca precyzuje w uzasadnieniu pisma, że art. 2 Konstytucji stanowi wzorzec kontroli w zakresie, w jakim wynika z niego zasada określoności przepisów prawa.

Zasada określoności prawa stanowi dyrektywę prawidłowej legislacji oraz jeden z elementów zasady ochrony zaufania do państwa i stanowionego przez nie prawa (wyroki TK z: 28 października 2009 r., sygn. akt K 32/08; 29 maja 2012 r., sygn. akt SK 17/09; 29 lipca 2014 r., sygn. akt P 49/13). Wynika z niej spoczywający na prawodawcy obowiązek formułowania przepisów prawnych, zwłaszcza dotyczących wolności i praw jednostki lub przewidujący możliwość stosowania wobec niej sankcji, w sposób poprawny, jasny i precyzyjny, tym samym zapewniający przewidywalność skutków jego zastosowania (por. wyroki TK z: 11 stycznia 2000 r., sygn. akt K 7/99; 12 czerwca 2002 r., sygn. akt P 13/01). $\mathrm{Z}$ tak ujętej zasady określoności wynika, że każdy przepis prawny powinien być skonstruowany poprawnie z punktu widzenia językowego i logicznego. Przepis powinien być klarowny i zrozumiały dla adresata, niebudzący wątpliwości co do treści nakładanych obowiązków i przyznawanych praw. Związana z jasnością precyzja przepisów winna przejawiać się również w konkretności nakładanych obowiązków i przyznawanych praw, tak aby pozwalała ona na ich egzekwowanie 
(zob. wyrok TK z 21 marca 2001 r., sygn. akt K 24/00). Konkretyzując ten obowiązek, Trybunał Konstytucyjny wskazał, że wymóg jasności oznacza nakaz tworzenia przepisów w sposób kompletny, precyzyjny i jednoznacznie definiujący wszystkie, w tym podmiotowe, znamiona czynów zagrożonych karą (zob. wyrok TK z 26 kwietnia 1995 r., sygn. akt K 11/94).

Niemniej nie każde naruszenie zasad techniki legislacyjnej stanowi jednocześnie złamanie konstytucyjnej zasady prawidłowej legislacji, a jedynie takie, które jest istotne. Do naruszenia wymogu określoności przepisów prawa dochodzi w sytuacji, gdy przepis jest sformułowany w sposób niejasny i nieprecyzyjny w stopniu powodującym istotne wątpliwości prawne, a także gdy posługuje się niezdefiniowanymi pojęciami albo mającymi niezrozumiałą treść (zob. wyroki TK z: 30 października 2001 r., sygn. akt K 33/00; 28 października 2009 r., sygn. akt Kp 3/09). Rygor stosowania tej zasady zależy także od rodzaju zagadnień będących przedmiotem regulacji prawnej. Niewątpliwie i w sposób kategoryczny odnosi się on do relacji między państwem a obywatelami jako adresatami przepisu prawnego. Stąd wszystkie przepisy ograniczające realizację wolności i praw jednostki muszą być dostatecznie określone (wyrok TK z 10 listopada 1998 r., sygn. akt K 39/97, zob. W. Sokolewicz, M. Zubik, Komentarz do art. 2 [w:] Konstytucja Rzeczypospolitej Polskiej. Komentarz, t. I, red. L. Garlicki, M. Zubik, Warszawa 2016, s. 147-148).

Wymóg określoności nie wyklucza posługiwania się przez ustawodawcę pojęciami pozaprawnymi, nawet nieostrymi, odwołującymi się do funkcjonujących w społeczeństwie przekonań i ocen, jeśli mają ugruntowaną w świadomości prawnej jednostek podstawę aksjologiczną, z której wynika konkretny imperatyw normatywny (zob. wyrok TK z 15 września 1999 r., sygn. akt K 11/99). Dopuszcza się również używanie pojęć, które ze swej istoty wymagają wykładni lub odwołują się do regulacji zawartych w innych gałęziach prawa (zob. wyrok TK z 12 września 2005 r., sygn. akt SK 13/05). Z brzmienia art. 2 Konstytucji nie można też wyprowadzać zakazu posługiwania się odesłaniem do innych aktów prawnych (postanowienie TK z 23 listopada 2004 r., sygn. akt Tw 25/04). Natomiast będzie sprzeczne z zasadą określoności odesłanie, które zawiera sformułowanie niedookreślone, prowadząc do niedających się usunąć wątpliwości co do zakresu naruszenia wolności człowieka (wyrok TK z 7 października 2015 r., sygn. akt K 12/14).

W wyroku z 6 października 2015 r. (sygn. akt SK 54/13) Trybunał Konstytucyjny sformułował swoisty test określoności prawa, który wymaga odpowiedzi na trzy problemy dotyczące: po pierwsze, precyzyjności regulacji prawnej (konkretność regulacji praw i obowiązków, tak by ich treść pozwalała na wyegzekwowanie); po drugie, jasności przepisu (zrozumiałość dla adresatów) oraz po trzecie, legislacyjnej poprawności (spełnienie wymogów co do technicznej strony legislacyjnej).

2. Wskazany we wniosku art. 31 ust. 3 Konstytucji dopuszcza ustanawianie ograniczeń w zakresie korzystania z konstytucyjnych wolności i praw. Zgodnie 
z jego brzmieniem: „Ograniczenia w zakresie korzystania z konstytucyjnych wolności i praw mogą być ustanawiane tylko w ustawie i tylko wtedy, gdy są konieczne w demokratycznym państwie dla jego bezpieczeństwa lub porządku publicznego, bądź dla ochrony środowiska, zdrowia i moralności publicznej, albo wolności i praw innych osób. Ograniczenia te nie mogą naruszać istoty wolności i praw".

Istotą unormowania zawartego $\mathrm{w}$ cytowanym przepisie konstytucyjnym jest wyznaczenie granic ingerencji władzy publicznej w sferę wolności i praw konstytucyjnych (tzw. granic ograniczeń) poprzez ogólne określenie przesłanek, których spełnienie jest konieczne do wprowadzenia ograniczeń praw i wolności jednostki. Został on skonstruowany z trzech części, z których pierwsza to ustalenie przesłanki formalnej (wymóg ustawowej formy ograniczeń); druga - określenie przesłanek materialnych (poprzez specyfikację pojęcia „interesu publicznego”) oraz trzecia - wskazanie maksymalnych granic dla wprowadzania ograniczeń (nakaz szanowania zasady proporcjonalności oraz zakaz naruszania „istoty” praw i wolności (L. Garlicki, K. Wojtyczek, Komentarz do art. 31 [w:] Konstytucja Rzeczypospolitej Polskiej. Komentarz, t. II, red. L. Garlicki, M. Zubik, Warszawa 2016, s. 72). Jest to przepis zawężający zakres zastosowania wolności i praw konstytucyjnie zagwarantowanych i tym samym musi być interpretowany zgodnie z zasadami wykładni wyjątków, w szczególności przy uwzględnieniu zakazu rozszerzającej interpretacji jego postanowień. Granicą dla wprowadzenia ograniczeń konstytucyjnych praw i wolności są zatem przesłanki „konieczności”, dopuszczalności $\mathrm{w}$ „demokratycznym państwie” oraz zakazu naruszania „istoty wolności i praw”.

W aspekcie formalnym ograniczenia korzystania z konstytucyjnych wolności i praw mogą być ustanawianie tylko w drodze ustawy. Jednak zachowanie ustawowej rangi unormowania ograniczeń wolności i praw nie jest wystarczające dla zachowania wymogu formalnoprawnego. W orzecznictwie Trybunału Konstytucyjnego podkreśla się, że: „ustawowe sformułowanie przepisów karnych (represyjnych) musi w sposób zupełny odpowiadać zasadzie określoności. Oznacza to, że sama ustawa musi w sposób kompletny, precyzyjny i jednoznaczny definiować wszystkie znamiona czynów zagrożonych karą. Obejmuje to oczywiście i element podmiotowy, to znaczy określenie zakresu osób, które są adresatami przepisu karnego. Ustawa musi więc w sposób kompletny wyznaczyć kategorie osób, które mogą ponosić odpowiedzialność za dany czyn. Nie może tego natomiast dokonywać akt wykonawczy, bo w prawie karnym wyłączność ustawy ma charakter bezwzględny. Wynika to z zasady nullum crimen sine lege, stanowiącej nieodłączny element państwa prawnego" (orzeczenie TK z 26 kwietnia 1995 r., sygn. akt K 11/94). Regulacja ustawowa musi zatem odpowiadać dwóm wymaganiom jakościowym. Po pierwsze, musi się cechować odpowiednim stopniem precyzji (określoności): przekroczenie pewnego poziomu niejasności przepisów prawnych stanowić może samoistną przesłankę stwierdzenia ich niezgodności z przepisem (art. 31 ust. 3 zdanie pierwsze) wymagającym regulacji ustawowej 
określonej dziedziny, np. ograniczeń w korzystaniu z konstytucyjnych wolności i praw (wyrok TK z 22 maja 2002 r., sygn. akt K 6/02). Po drugie, musi się cechować odpowiednim stopniem kompletności, czyli na poziomie ustawy muszą zostać unormowane wszystkie podstawowe elementy ograniczenia danego prawa lub wolności (wyrok TK z 18 lutego 2014 r., sygn. akt K 29/12).

$\mathrm{Z}$ uzasadnienia wnioskodawcy wynika ponadto, że z treści art. 31 ust. 3 Konstytucji wyprowadza on zasadę proporcjonalności. W orzecznictwie sądu konstytucyjnego nie budzi wątpliwości, że wspomniany przepis statuuje w sposób w pełni samodzielny i całościowy zasadę proporcjonalności (wyrok TK z 12 stycznia 1999 r., sygn. akt P 2/98). Świadczy o tym jego treść, która wskazuje, że ograniczenia konstytucyjnych praw i wolności mogą być ustanawiane tylko wtedy, „gdy są konieczne w demokratycznym państwie”. W ocenie TK zasada proporcjonalności: „[z] jednej strony stawia (...) przed prawodawcą każdorazowo wymóg stwierdzenia rzeczywistej potrzeby dokonania w danym stanie faktycznym ingerencji w zakres prawa bądź wolności jednostki. Z drugiej zaś winna być ona rozumiana jako wymóg stosowania takich środków prawnych, które będą skuteczne, a więc rzeczywiście służące realizacji zamierzonych przez prawodawcę celów. Ponadto chodzi tu o środki niezbędne, w tym sensie, że chronić będą określone wartości w sposób, bądź w stopniu, który nie mógłby być osiągnięty przy zastosowaniu innych środków. Niezbędność to również skorzystanie ze środków jak najmniej uciążliwych dla podmiotów, których prawa lub wolności ulegną ograniczeniu. Ingerencja w sferę statusu jednostki musi więc pozostawać w racjonalnej i odpowiedniej proporcji do celów, których ochrona uzasadnia dokonane ograniczenie. (...) «Konieczność», którą wyraża art. 31 ust. 3 Konstytucji mieści więc w sobie postulat niezbędności, przydatności i proporcjonalności sensu stricto wprowadzanych ograniczeń" (wyrok TK z 12 stycznia 1998 r., sygn. akt P 2/98).

Z powyższego wynika, że dla oceny, czy doszło do naruszenia zasady proporcjonalności, konieczne jest udzielenie odpowiedzi na pytanie, czy kwestionowana norma spełnia trzy wymagania: przydatności, konieczności i proporcjonalności sensu stricto. Te trzy kryteria stosowane powinny być do konkretnych unormowań odnoszących się do poszczególnych typów wolności i praw jednostki. Trybunał wskazuje tym samym, że zasada proporcjonalności ma charakter relatywny, bo różnicuje zakres dopuszczalnej ingerencji w zależności od tego, jakie wolności bądź prawa stają się przedmiotem tej ingerencji (orzeczenie TK z 26 kwietnia 1995 r., sygn. akt K 11/94). W orzecznictwie konstytucyjnym przyjmuje się, że im cenniejsze jest dobro ograniczane i wyższy jest stopień tego ograniczenia, tym cenniejsza musi być wartość uzasadniająca ograniczenia (wyrok TK z 25 lipca 2013 r., sygn. akt P 56/11).

3. Przywołany w charakterze wzorca kontroli art. 42 ust. 1 Konstytucji wyraża zasadę nullum crimen sine lege, nulla poena sine lege. Stanowi on, że: „[o]dpowiedzialności karnej podlega ten tylko, kto dopuścił się czynu zabronionego pod 
groźbą kary przez ustawę obowiązującą w czasie jego popełnienia. Zasada ta nie stoi na przeszkodzie ukaraniu za czyn, który w czasie jego popełnienia stanowi przestępstwo w myśl prawa międzynarodowego".

$\mathrm{Z}$ ogólnej zasady nullum crimen sine lege, nulla poena sine lege wyprowadzone są następujące zasady szczegółowe:

- nullum crimen, nulla poena sine lege scripta, zgodnie z którą źródłem określenia przestępstwa i kary kryminalnej może być tylko ustawa bądź akty równe ustawie,

- nullum crimen, nulla poena sine lege stricta, zgodnie z którą w prawie karnym zabronione jest stosowanie analogii mającej na celu poszerzenie zakresu kryminalizacji lub penalizacji, jak również dokonywanie wykładni rozszerzającej przepisu prawa karnego na niekorzyść sprawcy,

- nullum crimen, nulla poena sine lege certa, zgodnie z którą określenie przestępstwa i kary powinny charakteryzować się dostateczną precyzyjnością,

- nullum crimen, nulla poena sine lege praevia, zgodnie z którą zabronione jest wsteczne działanie ustawy karnej w takim zakresie, w jakim pogarsza to sytuację sprawcy (zob. R. Dębski, Pozaustawowe znamiona przestępstwa. O ustawowym charakterze norm prawa karnego i znamionach typu czynu zabronionego nie określonych w ustawie, Łódź 1995, s. 19-20; A Wąsek, Kodeks karny. Komentarz, t. I, Gdańsk 1999, s. 16-20).

Kwestia określoności norm karnych była podejmowana w dotychczasowym orzecznictwie Trybunału Konstytucyjnego. Jak wskazano w uzasadnieniu postanowienia z 25 września 1991 r. (sygn. akt S 6/91): „[w] demokratycznym państwie prawa funkcją prawa karnego nie jest tylko ochrona państwa i jego instytucji, nie jest także tylko ochrona społeczeństwa lub poszczególnych jednostek przed przestępstwami, ale także, $w$ nie mniejszym stopniu, ochrona jednostki przed samowolą państwa. Prawo karne stwarza dla władzy w demokratycznym państwie prawa barierę, poza którą obywatel powinien czuć się bezpieczny w tym sensie, że bez przekroczenia pola zabronionego pod groźbą kary nie może być pociągnięty do odpowiedzialności karnej. Prawo karne ma wyznaczyć wyraźne granice między tym, co jest dozwolone, a tym, co jest zabronione. Bariera, o której tu mowa, nie powinna być usuwana dla żadnych celów politycznych lub innych. Prawo karne nie jest bowiem instrumentem mającym służyć zachowaniu władzy, lecz jest właśnie tej władzy ograniczeniem”. Jak dalej wskazano: „[z] powyższych założeń wynika, że w demokratycznym państwie prawa prawo karne musi być oparte przynajmniej na dwóch podstawowych zasadach: określoności czynów zabronionych pod groźbą kary (nullum crimen, nulla poena sine lege) oraz na zakazie wstecznego działania ustawy wprowadzającej lub zaostrzającej odpowiedzialność karną (lex severior retro non agit)".

W myśl przytoczonych reguł warunkiem odpowiedzialności karnej jest określona ustawowo karalność czynu podlegającego ocenie w momencie jego 
popełnienia. Odpowiedzialność karna nie może być więc przewidziana w akcie podustawowym. Ustawa powinna przy tym w sposób precyzyjny, niebudzący jakichkolwiek wątpliwości, pozwolić na wskazanie czynu zabronionego i definiować wszystkie jego znamiona wyznaczające cechy tworzące zarys typu przestępstwa. W nauce prawa wskazuje się, że zasada nullum crimen sine lege, nulla poena sine lege wywiera wpływ na prawo karne na trzech płaszczyznach: stanowienia prawa, jako skierowany do prawodawcy postulat ustawowego określenia zagrożenia sankcją karną, jego stosowania - w postaci adresowanego do sądu nakazu wymierzenia tylko takiej kary, jaka została ustawowo przewidziana, oraz wykonywania - jako postulat ścisłego określania sposobu egzekwowania kary i wykonania jedynie kary oznaczonej przez orzekający w sprawie sąd (zob. B. Banaszak, Konstytucja Rzeczypospolitej Polskiej. Komentarz, Warszawa 2012, komentarz do art. 42, s. 275). Na podobnym stanowisku stoi Trybunał Konstytucyjny, stwierdzając: „[z]asada nullum crimen, nulla poena sine lege kreuje jedno z podstawowych praw człowieka. Wynikają z niej postulaty skierowane zarówno do ustawodawcy, jak i do podmiotów stosujących prawo" (wyrok TK z 16 marca 2011 r., sygn. akt K 35/08).

Ponadto art. 42 ust. 1 Konstytucji formułuje dyrektywę określoności przepisów karnych. Zakaz lub nakaz obwarowany sankcją karną musi być sformułowany ściśle, zgodnie z zasadą nullum delictum sine lege certa (zob. J. Warylewski, Zasady techniki prawodawczej. Komentarz do rozporzadzenia, Warszawa 2003, s. 326). Brak precyzji ustawodawcy stwarza szerokie pole dla dowolności działania organów stosujących prawo, a to istotnie zwiększa ryzyko bezpodstawnego stosowania sankcji. Podobny pogląd wyraził Trybunał Konstytucyjny, głosząc, że należy wykluczyć niedoprecyzowanie jakiegokolwiek elementu normy karnej, które pozwalałoby na dowolność jej stosowania przez właściwe organy władzy publicznej czy na zawłaszczenie przez te organy pewnych sfer życia i penalizowanie zachowań, które nie zostały expressis verbis określone jako zabronione w przepisie prawa karnego (zob. wyrok TK z 5 maja 2004 r., sygn. akt P 2/03). Jeżeli na skutek braku precyzji ustawodawcy pojawią się wątpliwości dotyczące treści normy prawa karnego, nie można stosować takiej wykładni przepisów, która byłaby na niekorzyść sprawcy czynu. Wiąże się z tym zakaz stosowania analogii i wykładni rozszerzającej (zob. wyrok TK z 6 lipca 1999 r., sygn. akt P 2/99). Konstytucja w art. 42 ust. 1 stanowi o czynie zabronionym. Jak zauważa Trybunał Konstytucyjny: „[c]hodzi zatem o konkretne (skonkretyzowane) zachowanie, jakie można przypisać pewnej jednostce. Jakkolwiek zachowanie to może polegać na różnych aktach (działaniu, zaniechaniu), nie budzi wątpliwości, iż na gruncie wspomnianego przepisu konieczne jest precyzyjne jego wskazanie (dookreślenie). W konsekwencji jakiekolwiek wskazanie ogólnikowe, umożliwiające daleko idącą swobodę interpretacji co do zakresu znamion czynu zabronionego czy pewnego typu kategorii zachowań, nie może być traktowane jako spełniające wymóg określoności na gruncie art. 42 ust. 1 Konstytucji. 
Z kolei w postanowieniu Trybunału Konstytucyjnego z 13 czerwca 1994 r. (sygn. akt S 1/94) podkreślono, że „[k]ażda regulacja prawna, nawet o charakterze ustawowym, dająca organowi państwowemu uprawnienie do wkraczania w sferę praw i wolności obywatelskich, musi spełniać warunek dostatecznej określoności. Należy przez to rozumieć precyzyjne wyznaczenie dopuszczalnego zakresu ingerencji oraz trybu, w jakim podmiot ograniczony w swoich prawach i wolnościach może bronić się przed nieuzasadnionym naruszeniem jego dóbr osobistych". „W demokratycznym państwie prawa każda forma naruszenia przez organ państwowy dobra osobistego musi łączyć się z możliwością kontroli zasadności działania organu państwowego" (orzeczenie TK z 19 czerwca 1992 r., sygn. akt U 6/92). Podkreślono przy tym, że w demokratycznym państwie prawa: „[w]ymaganie określoności dotyczyć musi zarówno materialnych elementów czynu, jak i elementów kary, tak by czyniło to zadość wymaganiu przewidywalności. Przepisy prawne muszą bowiem stwarzać obywatelowi (podmiotowi odpowiedzialności karnej) możliwość uprzedniego i dokładnego rozeznania, jakie mogą być prawnokarne konsekwencje jego postępowania. Materialne elementy czynu, uznanego za przestępny, muszą więc być zdefiniowane w ustawie (zgodnie z konstytucyjną zasadą wyłączności ustawy) w sposób kompletny, precyzyjny i jednoznaczny”. Wymóg określoności został również wyeksponowany w orzeczeniu Trybunału Konstytucyjnego z 1 marca 1994 r. (sygn. akt U 7/93), w którym wskazano, że: „[n]iesporne jest, iż w państwie prawnym przepisy karne winny precyzyjnie określać zarówno czyn jak i karę (...). Niesporne jest też, w świetle konstytucyjnego podziału materii pomiędzy ustawy a akty wykonawcze, że podstawowe elementy zarówno czynu jak i kary muszą być określone w samej ustawie, a nie mogą być - w sposób blankietowy - pozostawione do unormowania w akcie wykonawczym. Trybunał Konstytucyjny jest zdania, że powyższe konstytucyjne wymagania pod adresem przepisów karnych należy odnosić do wszystkich przepisów o charakterze represyjnym (sankcjonująco-dyscyplinującym), a więc do wszystkich przepisów, których celem jest poddanie obywatela jakiejś formie ukarania czy jakiejś sankcji”.

Nie oznacza to jednak, że ustawodawca nie może określać pewnych zachowań stanowiących czyn zabroniony w sposób na tyle ogólny, aby w ich zakresie mieściły się różne działania, które są zabronione np. ze względu na cel, jaki ma być osiągnięty przez ich realizację. Wniosek przeciwny należałoby uznać za absurdalny, w krańcowym bowiem ujęciu prowadziłby do konieczności zaprzeczenia abstrakcyjnego i ogólnego charakteru normy prawnej. Nie może jednak budzić wątpliwości, że jednostka w konkretnych okolicznościach narażona jest na odpowiedzialność karną (zob. wyrok TK z 26 listopada 2003 r., sygn. akt SK 22/02). Ponadto Trybunał Konstytucyjny stwierdził: „[r]ozważana zasada wyklucza odpowiedzialność karną na podstawie aktów normatywnych, nawet o mocy ustawy, ustanowionych przez organy bez odpowiednich kompetencji lub ustanowionych z naruszeniem przepisów proceduralnych" (wyrok TK z 16 marca 2011 r., sygn. akt K 35/08). 
4. Zagwarantowana $\mathrm{w}$ art. 54 ust. 1 Konstytucji wolność słowa określona została jako wolność wyrażania swoich poglądów oraz pozyskiwania i rozpowszechniania informacji. Stanowi fundament społeczeństwa demokratycznego i warunkuje równocześnie rozwój intelektualny jednostek (por. B. Banaszak, Konstytucja Rzeczypospolitej, op. cit., komentarz do art. 54, s. 330).

Wolność zapewniona w art. 54 ust. 1 Konstytucji ma dwa aspekty: po pierwsze, stwarza każdemu możliwość przekazywania pochodzących od niego wiadomości i idei innym osobom, a po drugie - zapewnia odbiorcy informacji prawo swobodnego wyboru ich źródła i zapewnia ich kształtowanie w drodze procesu społecznego, chronionego przed ograniczeniami jego pluralizmu ze względów politycznych, kulturalnych itp. Konstytucja nie definiuje pojęcia poglądu. Niemniej, opierając się na spostrzeżeniach nauki i orzecznictwie sądowym, można wskazać, że pojęcie to obejmuje wszystkie rodzaje wypowiedzi, zarówno dokonane w sposób werbalny, jak i inny (dzieło artystyczne, plastyczne, informacja o charakterze handlowym, reklama, utwór muzyczny) wyrażające informacje, opinie, idee niezależne od ich treści, oceny, co do faktów i zjawisk we wszystkich przejawach życia, jak również przypuszczenia i prognozy (zob. wyrok TK z 5 maja 2004 r., sygn. akt P 2/03). Oprócz wyrażania poglądów art. 54 ust. 1 Konstytucji zapewnia wolność pozyskiwania i rozpowszechniania informacji, rozumianych nie tylko jako danych dotyczących faktów, stanów i sytuacji, lecz także należy rozumieć je jako pochodzący od kogoś przekaz jego poglądów. Możliwość zapoznania się z pochodzącymi od innych informacjami ma fundamentalne znaczenie dla kształtowania własnych poglądów. Dlatego też wolność pozyskiwania i rozpowszechniania informacji jest ściśle związana $z$ wolnością wyrażania poglądów (por. wyrok Naczelnego Sądu Administracyjnego z 28 czerwca 2005 r., sygn. akt OSK 1733/04).

Jak zauważa Trybunał Konstytucyjny, podmiotem wolności słowa mogą być zarówno jednostki (osoby fizyczne), jak i podmioty zbiorowe, a wśród nich partie polityczne i komitety wyborcze, które składają się z osób fizycznych i w ich imieniu się wypowiadają (zob. wyrok TK z 20 lipca 2011 r., sygn. akt K 9/11). Trybunał uznał, że wolność słowa nie ma charakteru wyłącznie osobistego, a zatem nie można jej interpretować wyłącznie w kontekście indywidualnych praw człowieka i obywatela realizowanych w sferze ich życia prywatnego, lecz ma ona charakter mieszany, pozwalający na swobodne wyrażanie poglądów również w sferze życia publicznego i politycznego. Wolność wypowiedzi w życiu publicznym dotyczy ogółu społeczeństwa, a zatem podmiotu zbiorowego, przez co ma ona walory zasady ustrojowej istotnej dla demokratycznego funkcjonowania całego państwa.

Konstytucja w art. 54 ust. 1 nie formułuje żadnych klauzul ograniczających, z czego wynika, że przy określaniu granic tej wolności ma zastosowanie art. 31 ust. 3 Konstytucji. Oznacza to dopuszczalność ograniczeń wolności słowa tylko w drodze ustawy (zob. wyrok Sądu Najwyższego [dalej: SN] z 28 września 2000 r., 
sygn. akt V KKN 171/98) z poszanowaniem innych konstytucyjnie chronionych wartości oraz praw i wolności jednostki. Chodzi tu przede wszystkim o dobra osobiste, godność, cześć, prywatność, uczucia religijne. Sąd Najwyższy odrzucił możliwość powstania sytuacji, w której „w granicach pojęcia wolności wypowiedzi i dopuszczalnej krytyki mieści się nieskrępowana, nielicząca się z realiami dowolność w zniesławianiu wskazanych imiennie osób" (wyrok SN z 22 czerwca 2004 r., sygn. akt V KK 70/04). Pogląd ten wyraził także Trybunał Konstytucyjny w wyroku z 30 października 2006 r. (sygn. akt P 10/06), w którym zaaprobował jako zgodne z Konstytucją samą dopuszczalność karania za przekroczenie granic wolności wyrażania poglądów i równocześnie zaaprobował uzależnienie w prawie karnym przestępności zniesławienia od tego, czy sprawca działał w obronie uzasadnionego interesu.

\section{Analiza zgodności}

- 1. Analiza zgodności art. 55a ustawy o IPN z art. 42 ust. 1 w związku z art. 2 i w związku z art. 31 ust. 3 Konstytucji

1. Ustawa o IPN w art. 55a odnosi się do jednej z form tzw. kłamstwa historycznego i wprowadza nowy typ czynu zabronionego, polegającego na publicznym i wbrew faktom przypisywaniu Narodowi Polskiemu lub Państwu Polskiemu odpowiedzialności lub współodpowiedzialności za popełnione przez III Rzeszę Niemiecką zbrodnie nazistowskie lub za inne przestępstwa stanowiące zbrodnie przeciwko pokojowi, ludzkości lub zbrodnie wojenne bądź w inny sposób rażąco pomniejsza odpowiedzialność rzeczywistych sprawców tych zbrodni (art. 1 pkt 6 ustawy nowelizującej o IPN). Zagrożone zostało sankcją karną w postaci kary grzywny lub kary pozbawienia wolności do lat 3. Intencją ustawodawcy było stworzenie skutecznych narzędzi prawnych pozwalających na przeciwdziałanie rozpowszechnianiu wypowiedzi sprzecznych z prawdą historyczną oraz prowadzenie konsekwentnej polityki historycznej w zakresie ochrony dobrego imienia Rzeczypospolitej Polskiej i Narodu Polskiego.

Strona przedmiotowa przestępstwa ustanowionego w art. 55a ustawy o IPN polega na trzech rodzajach zachowań. Po pierwsze, sankcjonowane jest: „publiczne i wbrew faktom przypisywanie” Narodowi Polskiemu lub Państwu Polskiemu odpowiedzialności lub współodpowiedzialności za popełnione przez III Rzeszę Niemiecką zbrodnie nazistowskie określone w art. 6 Karty Międzynarodowego Trybunału Wojskowego załączonej do Porozumienia międzynarodowego w przedmiocie ścigania i karania głównych przestępców wojennych Osi Europejskiej, podpisanego w Londynie dnia 8 sierpnia 1945 r. (Dz. U. 1947, poz. 367; dalej: Karta). Artykuł 6 Karty określa zakres jurysdykcji Międzynarodowego Trybunału Wojskowego, do której należy sądzenie zbrodni przeciwko pokojowi, zbrodni wojennych oraz zbrodni przeciwko ludzkości, wszystkie zdefiniowane w dalszej części postanowień Karty. Po drugie, art. 55a ustawy o IPN penalizu- 
je „publiczne i wbrew faktom przypisywanie” Narodowi Polskiemu lub Państwu Polskiemu „odpowiedzialności lub współodpowiedzialności” za inne przestępstwa stanowiące zbrodnie przeciwko pokojowi, ludzkości lub zbrodnie wojenne. Ten rodzaj zachowania przestępczego dotyczy nie tylko czynów popełnionych w III Rzeszy Niemieckiej, lecz wszelkich zbrodni przeciwko pokojowi, ludzkości i zbrodni wojennych. Pojęcie zbrodni przeciwko ludzkości zostało zdefiniowane w art. 3 ustawy o IPN, zgodnie z którym są nimi „w szczególności zbrodnie ludobójstwa w rozumieniu Konwencji w sprawie zapobiegania i karania zbrodni ludobójstwa, przyjętej w dniu 9 grudnia 1948 r. (Dz. U. z 1952 r. poz. 9, 10 i 213 oraz z 1998 r. poz. 177), a także inne poważne prześladowania z powodu przynależności osób prześladowanych do określonej grupy narodowościowej, politycznej, społecznej, rasowej lub religijnej, jeżeli były dokonywane przez funkcjonariuszy publicznych albo przez nich inspirowane lub tolerowane". Trzecim rodzajem zachowania przestępnego, penalizowanego art. 55a ustawy o IPN, jest w inny sposób „rażące pomniejszanie” odpowiedzialności rzeczywistych sprawców zbrodni przeciwko pokojowi, ludzkości lub zbrodni wojennych, w tym także popełnionych przez III Rzeszę Niemiecką.

Wprowadzone art. 55a ustawy o IPN zachowania są penalizowane także w przypadku ich nieumyślnego popełnienia (art. 55a ust. 2 ustawy o IPN). Karane jest zachowanie wyczerpujące znamiona czynu określonego w art. 55a ust. 1 ustawy o IPN, nawet przy braku zamiaru naruszenia dobra prawnego w nim chronionego. Czyn zabroniony stypizowany w art. 55a ust. 2 został zagrożony odpowiednio niższą karą - karą grzywny lub karą ograniczenia wolności.

Wnioskodawca formułuje zarzut nieprecyzyjnego wskazania znamion czynu zabronionego z uwagi na zastosowany w art. 55a ustawy o IPN sposób wyznaczenia formy działania sprawcy. Jego wątpliwości budzi pojęcie „przypisania” użyte w kontekście odpowiedzialności Narodu Polskiego lub Państwa Polskiego. Uznaje je za pojęcie ocenne, implikujące trudności interpretacyjne. W pierwszej kolejności należy zauważyć, że zasada określoności prawa nie stawia wymogu jasności czy komunikatywności wyrażenia zakazu lub nakazu prawnego w stopniu absolutnym. Trybunał Konstytucyjny, wypowiadając się w wyroku z 12 września 2005 r. (sygn. akt SK 13/05), podkreślił, że: „[z]asada określoności ustawy karnej nie wyklucza (...) posługiwania się przez ustawodawcę zwrotami niedookreślonymi lub ocennymi, jeśli ich desygnaty można ustalić”. Rozwijając tę tezę, Trybunał zaznaczył, że: „sam kodeks karny operuje licznymi zwrotami niedookreślonymi, które nie mają wyłącznie na celu oznaczenia kwalifikowanej postaci przestępstwa. Wystarczy wskazać na art. $218 \$ 1$ k.k. - mówiący o oddziaływaniu «złośliwym», art. 304 k.k. - mówiący o "przymusowym położeniu», art. 311 k.k. - «istotne znaczenie», gdzie użycie takich zwrotów determinuje same znamiona czynu karalnego. Znaczenie tych określeń nie jest jednak ustalane w próżni prawnej, co mogłoby rodzić niepewność, lecz poprzez analizę dorobku doktryny, a zwłaszcza orzecznictwa sądowego, które autorytatywnie 
usuwa istniejące obiektywnie wątpliwości”. Ponadto, jak wskazuje $\$ 155$ pkt 1 załącznika do rozporządzenia Prezesa Rady Ministrów w sprawie „Zasad techniki prawodawczej” z 20 czerwca 2002 r. (t.j. Dz. U. 2016, poz. 283), jeżeli zachodzi potrzeba zapewnienia elastyczności tekstu aktu normatywnego, można posłużyć się określeniami nieostrymi, klauzulami generalnymi albo wyznaczyć nieprzekraczalne dolne lub górne granice swobody rozstrzygnięcia.

Dekodowanie znamion typu czynu zabronionego należy rozpocząć od poddania przepisu wykładni językowej, ponieważ, zgodnie z naczelną dyrektywą preferencji, interpretator powinien opierać się w pierwszej kolejności na wykładni językowej (zob. uchwałę SN z 21 września 2005 r., sygn. akt I KZP 29/2005). Natomiast zgodnie ze sztuką wykładni prawa normie należy przypisać znaczenie, jakie ma w języku potocznym (zob. L. Morawski, Zasady wykładni prawa, Warszawa 2014, s. 98), jakie nadawane jest w języku etnicznym (A. Korybski, L. Leszczyński, A. Pieniążek, Wstęp do prawoznawstwa, Lublin 2003, s. 137). Jak sam wnioskodawca wskazuje, zgodnie z definicją zawartą w Słowniku języka polskiego „przypisywać” oznacza „uznać kogoś, coś za sprawcę, za przyczynę czegoś, uznać, że ktoś, coś odznacza się jakimiś cechami” (Słownik języka polskiego, t. II, red. M. Szymczak, Warszawa 1995, s. 1001).

Pojęcie „przypisywania” należy wyjaśniać w kontekście, w jakim zostało użyte w ustawie o IPN. Zastosowany w art. 55a ustawy o IPN zwrot „przypisuje Narodowi Polskiemu lub Państwu Polskiemu odpowiedzialność lub współodpowiedzialność" oznacza, że czynność sprawcza opisywanego przestępstwa zawiera się w obciążaniu odpowiedzialnością za zbrodnie wymienione w art. 55a ustawy o IPN Państwa Polskiego lub całego Narodu Polskiego bądź też polega na wskazywaniu ich jako sprawców lub organizatorów wymienionych zbrodni. Sprawca czynu twierdzi więc, że autorem zbrodni nazistowskich popełnionych przez III Rzeszę, określonych w art. 6 Karty Międzynarodowego Trybunału Wojskowego lub innych przestępstw stanowiących zbrodnie przeciwko pokojowi, ludzkości lub zbrodnie wojenne był Naród Polski lub Państwo Polskie. Przedstawia jako pewne i prawdziwe zdarzenia niemające potwierdzenia w faktach, które wpływają negatywnie na dobre imię Narodu Polskiego i Państwa Polskiego. W ten sposób dobro chronione przepisem art. 55a ustawy o IPN zostało określone w tytule rozdziału 6c ustawy o IPN „Ochrona dobrego imienia Rzeczypospolitej Polskiej i Narodu Polskiego”. Jest nim dobre imię Rzeczypospolitej Polskiej i Narodu Polskiego, czyli godność narodowa i państwowa. Szeroką wykładnię pojęcia „naród” przedstawił Trybunał Konstytucyjny, który w wyroku z 21 września 2015 r. (sygn. akt K 28/13), rekonstruując treść tego pojęcia, odwołał się nie tylko do preambuły Konstytucji, ale i do innych jej przepisów, w których to pojęcie występuje. Trybunał słusznie wskazał, że wyprowadzając treść pojęcia „naród” z Konstytucji nie można ograniczać się jedynie do tekstu preambuły, gdyż zwrot ten występuje w tekście Konstytucji także w innych kontekstach, wpływających na jego zakres treściowy. Powołując się na art. 5, 6 i 35 Konstytucji, Trybunał 
wskazał, że: „[u]strojodawca traktuje naród polski (pisany małymi literami) jako wspólnotę nie tyle etniczną (w ścisłym znaczeniu «wspólnoty krwi», co byłoby bezprzedmiotowe wobec migracji i mieszania się różnych narodowości zarówno w wielonarodowej I i II Rzeczypospolitej, jak i w wyniku wojen i przemarszów obcych armii), ile kulturową. Tę zaś definiuje się jako trwającą przez pokolenia wspólnotę związaną wielorakimi więziami - między innymi krwi, języka, kultury, religii, w której w różnych okolicznościach i czasach poszczególne z tych więzi uznawane są za pierwszoplanowe" (wyrok TK z 21 września 2015, sygn. akt K 28/13). W przywołanym wyroku Trybunał Konstytucyjny podkreślił ponadto, że w piśmiennictwie: „rozumie się przez naród polski (...) trwałą wspólnotę (czy też społeczność) mówiącą językiem polskim, związaną wspólną przeszłością (historycznie ukształtowaną) i kulturą, mającą wspólne interesy polityczne i gospodarcze, żywiącą poczucie odrębności od innych narodów oraz nacechowaną istnieniem poczucia państwowego (pragnieniem posiadania i umacniania własnego państwa), urzeczywistnionego przez posiadanie polskiego obywatelstwa". Trybunał zauważył, że: „sprzeczne są natomiast stanowiska co do zaliczania do Narodu Polskiego w rozumieniu kk i kw [Kodeksu karnego i Kodeksu wykroczeń - uwaga J.B.] osób deklarujących polską narodowość, ale nieposiadających obywatelstwa polskiego (problemem jest tu aksjologicznie nieuzasadniona nierówna ochrona Polonii - osób zamieszkałych na emigracji, poczuwających się do przynależności do narodu polskiego, ale zróżnicowanych pod względem posiadanego obywatelstwa, a ściśle osób nieposiadających obywatelstwa polskiego $\mathrm{z}$ racji zmiany pokoleniowej albo pozbawienia go przez władze komunistyczne" (ibidem). Niektórzy konstytucjonaliści także dostrzegają, że określenie Narodu Polskiego zawarte w preambule Konstytucji jest niepełne i nie może być zacieśnione tylko do ogółu obywateli polskich. W literaturze można odnaleźć pogląd, według którego: „obywatele aktualnie tworzący «Naród Polski» pozostają «złączeni więzami wspólnoty z naszymi rodakami rozsianymi po świecie (...), więc pojmowanie narodu wykracza poza aktualną sumę obywateli RP. Jest to zarazem potwierdzeniem, że twórcy wstępu nie zamierzali formułować prawniczo precyzyjnych definicji narodu polskiego, nie byłoby to zresztą ani możliwe, ani potrzebne (...) Konstytucyjne pojęcie narodu polskiego nie może być zacieśniane tylko do ogółu osób narodowości polskiej»" (Konstytucja Rzeczypospolitej Polskiej. Komentarz, t. I, red. L. Garlicki, M. Zubik, Warszawa 2016). Wydaje się, że ze względu na rodzaj dobra chronionego w art. 55a ustawy o IPN, jakim jest godność narodowa i państwowa, pojęcie Narodu Polskiego należy interpretować szerzej niż tylko na podstawie preambuły Konstytucji. Naród Polski jest to zatem nie tylko prosta suma pojedynczych obywateli, ale podmiot zbiorowy, całość połączona wspólną tożsamością, kulturą, historią, poczuciem przynależności do Narodu Polskiego, nie ograniczona do osób posiadających polskie obywatelstwo, co pozwala zaliczać do Narodu Polskiego również osoby żyjące poza granicami Rzeczypospolitej, a więc osoby niemające polskiego obywatelstwa, ale ma- 
jące poza polskim pochodzeniem duchowe i kulturowe więzy z Ojczyzną (zob. A. Grześkowiak, Przepis art. 55a ustawy o Instytucie Pamięci Narodowej - Komisji Ścigania Zbrodni przeciwko Narodowi Polskiemu w relacji do art. 55 tej ustawy oraz art. 133 KK, BAS 421/18, s. 4 i s. 16)². Natomiast pojęcie Państwa Polskiego, którego dobre imię jest przedmiotem ochrony $\mathrm{w}$ art. 55a ustawy o IPN, powinno być interpretowane jak przy czynie zabronionym z art. 133 ustawy z 6 czerwca 1997 r. - Kodeks karny (t.j. Dz. U. 2017, poz. 2204, ze zm.; dalej: k.k.), dotyczącym znieważania Narodu Polskiego lub Rzeczypospolitej Polskiej. Niewątpliwie oznacza ono nazwę państwa polskiego, niemniej nie powinno być ograniczane do jego poszczególnych instytucji organizacyjnych. Chodzi o państwo jako całość, rozumianą jako polityczny organizm składający się z terytorium, ludności i suwerennej władzy, występujący w sferze stosunków prawnomiędzynarodowych (por. J. Makarewicz, Kodeks karny z komentarzem, Lwów 1938, s. 404; L. Peiper, Kodeks karny i prawo o wykroczeniach, Kraków 1933, s. 434). Na takie rozumienie „Rzeczypospolitej Polskiej” wskazuje Trybunał Konstytucyjny w cytowanym już wyroku z 21 września 2015 r. (sygn. akt K 28/13), zgodnie z którym: „[w] świetle art. 1 Konstytucji RP, należy przyjąć, że Rzeczpospolita Polska to nazwa państwa polskiego, stanowiącego dobro wspólne wszystkich obywateli. Samo zaś «dobro wspólne» odnosi się do całej wspólnoty ludzkiej, zorganizowanej w państwo. Owo dobro jest sumą «warunków życia społecznego umożliwiających i ułatwiających integralny rozwój (...) członków wspólnoty politycznej» (M. Piechowiak, Dobro wspólne jako fundament polskiego porządku konstytucyjnego, Warszawa 2012, s. 433). Podkreśla się, że «to nie państwo jako dobro wspólne jest wspólnotą obywatelską, lecz odwrotnie - państwo jako wspólnota obywatelska staje się dobrem wspólnym» (W. Sokolewicz, Uwaga 6 do art. 1 [w:] Konstytucja Rzeczypospolitej Polskiej. Komentarz, t. V, red. L. Garlicki, Warszawa 2007)".

Trzeba zatem uznać, że dobrem chronionym w art. 55a ustawy o IPN jest ochrona dobrego imienia Narodu Polskiego, rozumianego jako określona zbiorowość stanowiąca całość, oraz Państwo Polskie, również pojmowane jako zorganizowana całość. Odpowiedzialność karna będzie zatem dotyczyła obciążania "Narodu Polskiego” lub „Państwa Polskiego”, a nie konkretnych Polaków, którzy dopuścili się zbrodni określonych w art. 55a ustawy o IPN. Przepis art. 55a ustawy o IPN pozostawia poza zakresem normowania przypisywanie odpowiedzialności lub współodpowiedzialność za popełnione przez III Rzeszę Niemiecką zbrodnie nazistowskie pojedynczym Polakom czy nawet Polakom działającym w grupie lub nawet zorganizowanej grupie. Nie stanowią oni bowiem Narodu Polskiego. Niewystarczające dla wyczerpania znamion czynów zabronionych w art. 55a ustawy o IPN będzie również użycie określenia wskazującego jedynie na narodowość sprawcy („Polak”), a nie na zbiorowość, jaką jest naród. Przy-

2 Zamieszczona w niniejszym numerze „Zeszytów Prawniczych BAS” na s. 148-172 przypis redakcji. 
pisanie odpowiedzialności musi odnosić się nie do konkretnych, pojedynczych osób narodowości polskiej, lecz do całego Narodu Polskiego (zob. P. Palka, Zakres penalizacji art. 55a ust. 1 i 2 ustawy o IPN w kontekście konstytucyjnych zasad odpowiedzialności karnej - opinia prawna, BAS 421/18, s. 15).

Na gruncie art. 55a ustawy o IPN czynność „przypisywania” odnosi się do działań podejmowanych „publicznie” oraz „wbrew faktom”. Przypisywanie określonych zbrodni powinno odbywać się publicznie, tzn. w sposób jawny, nie prywatny, gdy może być dostrzeżone przez bliżej nieokreśloną liczbę osób lub gdy następuje w miejscu dostępnym dla bliżej nieokreślonej liczby osób, nawet jeżeli w chwili zachowania sprawcy nikt poza nim samym tam się nie znajdował (por. wyrok TK z 21 września 2015 r., sygn. akt K 28/13). Drugą okolicznością określającą czynność sprawczą jest przypisywanie odpowiedzialności lub współodpowiedzialności wbrew faktom. Wynika stąd wniosek, że zarzut powinien ograniczać się do faktów, czyli stwierdzenia zgodnego z rzeczywistym stanem rzeczy, pewnego, stwierdzonego i bezspornego. Na gruncie ustawy, faktami będą zbrodnie, których zaistnienie na przestrzeni długiego czasu potwierdziły liczne dowody, a ich sprawstwo nie budzi wątpliwości. Jednocześnie fakty te wskazują, że ani Naród Polski, ani Państwo Polskie nie uczestniczyły w popełnianiu zbrodni określonych w art. 55a ustawy o IPN i tym samym nie można przypisywać im odpowiedzialności lub współodpowiedzialności za ich popełnienie (zob. A. Grześkowiak, Przepis art. 55a ustawy, op. cit., s. 4 i s. 18). Kategoryczne sformułowanie „wbrew faktom" nakłada obowiązek dowiedzenia, że określone wydarzenie historyczne i okoliczności z nim związane dotyczące sprawstwa tych wydarzeń są sprzeczne z rzeczywistym stanem rzeczy ustalonym w paradygmacie badań historycznych [Stanowisko Sejmu w sprawie z wniosku Rzecznika Praw Obywatelskich (sygn. akt K 29/08), dotyczącego ustawy z dnia 27 lipca 2001 r. - Prawo o ustroju sądów powszechnych, „Zeszyty Prawnicze BAS” 2009, nr 1(21), s. 243] lub takim względem, którego wystarczające będzie odwoływanie się do faktów notoryjnych (zob. A. Janisławski, P. Konopka, Zagadnienie penalizacji „kłamstwa oświęcimskiego”, „Palestra” 2009, nr 1-2, s. 55). Poza zakresem stosowania przepisu art. 55a ustawy o IPN będzie zatem wszystko to co - z powodu: sporów naukowych, braku odwzorowania w dokumentach źródłowych, etapu badań sprowadzającego się do niepotwierdzonych hipotez badawczych czy też konstytuujących dopiero twórcze myślenie etapów preparacji, inkubacji i olśnienia - faktem nazwać jeszcze się nie da (zob. P. Palka, Zakres penalizacji art. 55a, op. cit., s. 8).

Przedstawiona analiza wskazuje zatem, że zarówno dobro chronione, jak i czynność sprawcza określone zostały w sposób pozwalający na rekonstrukcję treści normy prawnej ujętej w art. 55a ustawy o IPN oraz przeprowadzenie poprawnego procesu jej stosowania, w wyniku czego kwestionowany przepis pozostaje w zgodzie z zasadą określoności przepisów prawa.

Nie można zgodzić się z wnioskodawcą, że pojęcie „przypisywanie działania” nie jest terminem prawnym, lecz tylko stosowanym w doktrynie prawa. Przywo- 
łany we wniosku przykład art. 130 ustawy z 6 września 2001 r. - Prawo farmaceutyczne (Dz. U. 2017, poz. 2211) odnoszący się do „przypisywania właściwości produktu leczniczego", świadczy o tym, że termin ten jest obecny w języku prawnym. Również i w tym wypadku wykładnia językowa nie pozostawia wątpliwości, pozwalając wskazać, że „przypisywanie” właściwości produktu leczniczego to uznanie, że dany produkt ma cechy właściwe dla produktu leczniczego. Na takie znaczenie inkryminowanych terminów z art. 130 ustawy - Prawo farmaceutyczne wskazuje również doktryna prawa (zob. L. Wilk, Komentarz do art. 130 [w:] Prawo farmaceutyczne. Komentarz, red. L. Ogiegło, Warszawa 2015, s. 990).

2. Zarzut naruszenia zasady określoności przepisów prawa wnioskodawca formułuje również $\mathrm{w}$ odniesieniu do penalizowanych czynów polegających na „rażącym” pomniejszaniu odpowiedzialności rzeczywistych sprawców zbrodni określonych w art. 55a ustawy o IPN. Pomniejszanie zbrodni musi się dokonywać w inny sposób niż przypisywanie ich Narodowi Polskiemu lub Państwu Polskiemu. Penalizowane jest tylko takie umniejszanie odpowiedzialności rzeczywistych sprawców zbrodni, które można uznać za „rażące”. Niewątpliwie ustawodawca posłużył się zwrotem niedookreślonym i ocennym, który nie jest jednak obcy w języku prawnym. Ratyfikowany przez Polskę Protokół dodatkowy do Konwencji Rady Europy o cyberprzestępczości dotyczący penalizacji czynów o charakterze rasistowskim lub ksenofobicznym popełnionych przy użyciu systemów komputerowych z 28 stycznia 2003 r. (Dz. U. 2015, poz. 730) w art. 6 zobowiązuje państwa-strony do podjęcia środków prawnych i innych dla uznania za przestępstwo w jej prawie wewnętrznym umyślne i bezprawne zaprzeczanie, poważne umniejszanie znaczenia, akceptację lub usprawiedliwianie zbrodni ludobójstwa oraz zbrodni przeciwko ludzkości. Strony Konwencji zgodziły się, że pomniejszanie znaczenia zbrodni musi osiągnąć pewien poziom - „poważny”. Podobnie, kwestia prawnokarnego zakresu art. 55a została ujęta w decyzji ramowej Rady 2008/913 z 23 listopada 2008 r. w sprawie zwalczania pewnych form i przejawów rasizmu i ksenofobii za pomocą środków prawnokarnych, która zobowiązała państwa członkowskie Unii Europejskiej do ustanowienia karalności umyślnych czynów polegających na publicznym aprobowaniu, negowaniu lub rażącym pomniejszaniu zbrodni przeciwko pokojowi, wojennych i przeciwko ludzkości, określonych w art. 6 statutu Międzynarodowego Trybunału Wojskowego, skierowanych przeciwko grupie osób, którą definiuje się według rasy, koloru skóry, wyznawanej religii, pochodzenia albo przynależności narodowej lub etnicznej, lub przeciwko członkowi takiej grupy, jeśli czyny takie mogą podburzać do przemocy lub wzbudzać nienawiść skierowaną przeciwko tej grupie lub jej członkowi. Wyrażenie „rażąco” jest także znane prawu karnemu (np. art. $68 \$ 2$ k.k.; art. 75 $\$ 1$ la k.k.). Jego synonimem jest „rzucający się w oczy”, „wyraźny”, „bardzo duży” (http://sjp.pwn.pl/sjp/razacy;2514202.html). Na gruncie art. 55a ustawy o IPN należy przyjąć, że odpowiedzialność ponosi ten, kto drastycznie, w sposób bezpodstawny, wyraźny, rozpoznawalny dla przeciętnego odbiorcy, minimalizuje za- 
miar lub skalę wymienionych w nim zbrodni (zob. K. Kaczmarczyk-Kłak, Ocena zgodności z Konstytucja RP nowelizacji ustawy o Instytucie Pamięci NarodowejKomisji Ścigania Zbrodni Przeciwko Narodowi Polskiemu, w szczególności dodanego art. 55a, BAS 472/18, s. 12) ${ }^{3}$. Warto dodać, że w sytuacji posłużenia się przez ustawodawcę zwrotem niedookreślonym funkcję gwarancyjną prawa karnego wspomaga odwołanie się do zobiektywizowanych ocen społecznych - pozwalających ustalić, jakie zachowania powinny być interpretowane jako wypełniające znamiona danego czynu zabronionego. Nie ma tu miejsca na całkowitą dowolność. Zadanie wypracowania akceptowalnych społecznie mierników w tej materii spoczywa jednak na organach wymiaru sprawiedliwości, odwołujących się do zobiektywizowanych norm kulturowo-obyczajowych. Użyty zatem w skarżonym przepisie zwrot „rażąco pomniejsza” nie budzi zastrzeżeń co do możliwości określenia istoty czynu zabronionego $\mathrm{z}$ art. 55a ust. 1 ustawy o IPN.

3. Zgodnie z zarzutami przedstawionymi w piśmie procesowym, analizy zgodności kwestionowanego przepisu z zasadą określoności przepisów prawa należy dokonać także z perspektywy kontratypu tzw. działalności artystycznej i naukowej, zawartego w art. 55a ust. 3 ustawy o IPN. Sprawca, który publicznie i wbrew faktom przypisuje umyślnie lub nieumyślnie Narodowi Polskiemu lub Państwu Polskiemu odpowiedzialność za zbrodnie nazistowskie lub inne albo w inny sposób rażąco umniejsza odpowiedzialność rzeczywistych sprawców tych zbrodni i który czyni to w ramach działalności artystycznej lub naukowej - dopuszcza się przekroczenia normy sankcjonowanej zakodowanej w typach czynów zabronionych $z$ art. 55a ust. 1 ustawy o IPN, jednak działanie jego nie będzie uznane za bezprawne. Wyznaczając granice bezprawności czynu określonego w art. 55a ustawy o IPN wolnością działalności twórczej oraz wolnością badań naukowych, ustawodawca uznał, że stanowią one dobro obiektywnie cenniejsze niż dobro poświęcane. Ocena zaistnienia okoliczności kontratypowej będzie zależała od tego, czy działanie naruszające normę sankcjonowaną było ukierunkowane na ochronę wartości co najmniej równych tym naruszonym. Ocena ta jest konieczna ze względu na kolizję dóbr będących podstawą wszystkich kontratypów, w tym kontratypu z art. 55a ust. 3 ustawy o IPN. Istotne jest zatem ustalenie znaczenia pojęcia działalności twórczej i naukowej.

Wolność artystyczna jest jedną z wolności, na których oparte jest demokratyczne państwo prawa. Nie ma ona jednak charakteru absolutnego i podlega ograniczeniom zgodnie z art. 31 ust. 3 Konstytucji. Pojęcie twórczości artystycznej nie zostało bliżej określone w Konstytucji, co nakazuje sięgnięcie do powszechnie przyjętego jego rozumienia. Odnosząc się do wolności artystycznej zagwarantowanej w art. 73 Konstytucji, można wskazać za poglądami doktryny, że pojęcie to łączy w sobie dwie cechy. Po pierwsze, dotyczy „twórczości”, więc

\footnotetext{
Zamieszczona w „Przeglądzie Sejmowym” 2018, nr 3(146), s. 168-178 - przypis redakcji.
} 
działań polegających na samodzielnym kreowaniu dzieła cechującego się przymiotem nowości (proste odtwarzanie dzieł już istniejących nie może być kwalifikowane jako „twórczość”, a co najwyżej jako „działalność artystyczna”, chyba że łączy się z nadawaniem dziełu nowej interpretacji, wyrażającej własne myśli czy koncepcje twórcy). Dzieło to może przybierać najrozmaitsze formy: tradycyjnie wiązane ze światem sztuki (literatura, malarstwo, rzeźba, utwory muzyczne, sztuki teatralne, film), a także formy niekonwencjonalne, wynikające $\mathrm{z}$ indywidualności artysty. Po drugie, twórczość ta musi mieć charakter „artystyczny”, co odróżnia ją od innych rodzajów twórczości. Musi więc ona, z jednej strony, nieść w sobie cechy przekazu określonej myśli czy idei (odzwierciedlać osobistą wizję świata artysty, ale czasem także jego poglądu na ten świat), a z drugiej - dokonywać tego przekazu w szczególnej formie wyrazu, oddziałującej na odczucia estetyczne odbiorcy. Uznanie dzieła za „twórczość artystyczną” nie może być uzależniane od powszechności jego odbioru (zob. L. Garlicki, M. Zubik, Komentarz do art. 73 [w:] Konstytucja Rzeczypospolitej Polskiej. Komentarz, t. II, red. L. Garlicki, M. Zubik, Warszawa 2016, s. 481). Skoro wolność działalności artystycznej, o której mowa w art. 73 Konstytucji, zagwarantowana została każdemu, należy przyjąć, że pojęcie to nie zostało ograniczone podmiotowo. W przypadku działalności artystycznej wartościami wskazującymi na społeczną opłacalność naruszenia dóbr chronionych przepisem art. 55a ust. 1 i 2 ustawy o IPN będą np. świadomość historyczna, kształtowanie tej świadomości, edukacja (zob. T. Gardocka, Czy w polskim prawie karnym potrzebny jest kontratyp sztuki?, „Palestra” 2015, nr 1-2, s. 28).

Pojęcie badań naukowych również nie zostało bliżej określone w Konstytucji, niemniej z powszechnie przyjętego jego rozumienia wynika, że cechą „nauki” podobnie jak „sztuki” - jest twórczy charakter, tzn. samodzielne kreowanie dzieła, cechującego się przymiotem nowości. Nie będzie nim proste odtwarzanie dzieł już istniejących. Celem nauki jest opis rzeczywistości w najróżniejszych jej aspektach i nadanie temu opisowi systematycznego i teoretycznie uporządkowanego charakteru. Zarazem - w odróżnieniu od sztuki - istotą nauki jest obiektywnie weryfikowalny charakter dokonywanych ustaleń, przede wszystkim w oparciu o kryterium prawdy (zob. L. Garlicki, M. Zubik, Komentarz do art. 73 [w:] Konstytucja Rzeczypospolitej, op. cit., s. 481). Można zatem uznać, że celem działalności naukowej jest poszukiwanie i uzasadnianie prawdy o danej rzeczywistości. Tym samym ustalenie wartości poszczególnych dzieł naukowych, a zwłaszcza ustalenie, czy w ogóle mają one charakter naukowy, może łatwiej następować przy wykorzystaniu powszechnie uznanych, obiektywnych kryteriów oceny i weryfikacji (M. Jabłoński, Wolności z art. 73 Konstytucji $R P$ [w:] Prawa $i$ wolności obywatelskie w Konstytucji RP, red. B. Banaszak, A. Preisner, Warszawa 2002, s. 556). Działalność naukowa obejmuje dwa elementy: badania naukowe (tzn. proces gromadzenia danych dających podstawę powstaniu dzieła naukowego, tworzenie tego dzieła i jego publiczna prezentacja) oraz nauczanie 
(tzn. proces systematycznego przekazywania wiedzy naukowej innym osobom, $\mathrm{z}$ reguły prowadzony $\mathrm{w}$ ramach zakładu nauczającego). Zakres podmiotowy wolności badań naukowych należy określić szeroko. Pojęcie „każdy”, o którym traktuje przepis art. 73 Konstytucji, odnosić trzeba więc do obywateli polskich, cudzoziemców i bezpaństwowców będących pracownikami naukowymi posiadającymi stopnie i tytuły naukowe i powiązanych z instytucjami naukowymi, do asystentów i studentów placówek naukowych, ale też i do osób niepozostających w jakimkolwiek stosunku pracy z jakąkolwiek uczelnią (zob. S. Jarosz-Żukowska, Ł. Żukowski, Wolność badań naukowych i nauczania [w:] Realizacja i ochrona konstytucyjnych wolności i praw jednostki w polskim porzadku prawnym, red. M. Jabłoński, Wrocław 2014, s. 718). Przyjmując taką interpretację pojęcia działalności artystycznej i naukowej, wynikającą z konstytucyjnego ujęcia wolności uregulowanej w art. 73 Konstytucji, należy opowiedzieć się za szerokim rozumieniem kontratypu wskazanego w art. 55a ust. 3 ustawy o IPN. Pogląd ten pozostaje w zgodzie z treścią art. 31 ust. 3 Konstytucji, zgodnie z którym każda ingerencja w sferę wolności powinna być uzasadniona. Skoro na gruncie art. 73 Konstytucji przyjęto bardzo szerokie ujęcie „twórczości artystycznej” i „badań naukowych” zawężenie rozumienia tych terminów nie spełniałoby testu proporcjonalności (zob. K. Kaczmarczyk-Kłak, Ocena zgodności z Konstytucja, op. cit., s. 8-9).

Reasumując dotychczasową część analizy, ustalenie znaczenia użytych przez ustawodawcę pojęć - mimo braku ich definicji legalnych - nie powinno rodzić, w opinii Sejmu, poważniejszych trudności organów stosujących prawo. W ocenie Sejmu istnieje możliwość określenia zachowań, dla których pole kryminalizacji wyznacza art. 55a ustawy o IPN, co pozwala uznać, że kwestionowany przepis nie narusza art. 2, art. 42 ust. 1 oraz art. 31 ust. 3 Konstytucji w zakresie zasady określoności przepisu karnego.

4. Wątpliwości wnioskodawcy dotyczą również zgodności art. 55a ustawy o IPN z art. 42 ust. 1 w związku z art. 31 ust. 3 Konstytucji, z uwagi na nieproporcjonalnie wysoką sankcję. Należy zauważyć, że wnioskodawca nie kwestionuje zasadności wprowadzenia regulacji prawnych przewidzianych w nowelizowanej ustawie o IPN, w tym przepisu karnego sankcjonującego przypisywanie Narodowi Polskiemu lub Państwu Polskiemu odpowiedzialności za zbrodnie określone w art. 55a ustawy o IPN. Co więcej, wprowadzenie wskazanych regulacji prawnych uważa za zasadne. Podkreśla jednocześnie, że poszukiwanie prawdy historycznej, będące integralną częścią swobody wypowiedzi, nie może prowadzić do negowania bezspornych faktów (wniosek, s. 3). Potwierdzona została zatem społeczna szkodliwość przedmiotowych zachowań oraz konieczność ich penalizacji, wynikająca z braku realnej możliwości zapobieżenia im za pomocą innych środków aniżeli prawnokarnych. W szczególności niewystarczające okazały się instrumenty cywilnoprawne i dyplomatyczne (zob. M. Filar, M. Berent, Opinia prawna w przedmiocie poselskiego projektu ustawy o zmianie ustawy I Instytucie Pamięci Narodowej - Komisji Ścigania Zbrodni przeciwko Narodowi Polskiemu 
oraz ustawy - Kodeks karny z 4.2.2014 r., (druk 1958), BAS, http://orka.sejm.gov. pl/rexdomk7.nsf/Opdodr?OpenPage\&nr=1958).

Zwalczaniu wskazanych czynów nie mogą także służyć art. 133 k.k., art. 255257 k.k. czy art. 55 ustawy o IPN, mimo że niekiedy może dojść do zbiegu przedmiotowego zakresu regulacji z art. 55a ustawy o IPN. Kwestionowana regulacja jest zatem konieczna dla realizacji założonego przez ustawodawcę celu, ponieważ brakuje innych, równie dolegliwych instrumentów, mogących skutecznie zapobiegać naruszeniom chronionego w tym przepisie dobra, jakim jest godność Narodu Polskiego i Rzeczypospolitej Polskiej. Dobre imię jest podstawowym składnikiem czci. Cześć to dobro, którego istotą jest ustosunkowanie się do danego podmiotu innych podmiotów (zob. W. Kulesza, Zniesławienie i zniewaga (Ochrona czci i godności osobistej człowieka w polskim prawie karnym - Zagadnienia podstawowe), Warszawa 1984, s. 33). Dobre imię składa się na cześć „zewnętrzną”, poważanie, jakim się cieszy dany podmiot w opinii publicznej. Inaczej można ją nazwać czcią społeczną w rozumieniu oceny w stosunkach społecznych (zob. W. Makowski, Kodeks karny, Warszawa 1933, s. 571, 572). Na tle przepisu art. 55a ustawy o IPN można uznać, że chodzi tu o aspekt obiektywny ochrony czci, tzn. o ocenę Państwa Polskiego i Narodu Polskiego jako szczególnych podmiotów zbiorowych w stosunkach międzynarodowych. Dobrem chronionym bezpośrednio jest zatem Rzeczpospolita Polska i Naród Polski widziane przez ich pozycję i należną im cześć w sferze publicznej (zob. A. Grześkowiak, Przepis art. 55a ustawy, op. cit., s. 4 i s. 15). Zniesławiające i niemające pokrycia w faktach zarzuty zaliczające Naród Polski i Państwo Polskie do sprawców, na których ciąży popełnienie zbrodni przeciwko pokojowi, ludzkości lub zbrodni wojennych, stanowi pomówienie godzące w cześć i dobre imię Narodu Polskiego i Państwa Polskiego. Relatywizowanie wydarzeń historycznych, które stanowią dziedzictwo pamięci wspólnoty i jej poszczególnych członków, o bezprecedensowym charakterze, uznawane za fakt bezsporny, godzi w poczucie przynależności narodowej i wywołuje poczucie krzywdy, kształtując wśród opinii publicznej rażąco nieprawdziwy wizerunek Polski i przypisując Polakom cechy odzierające ich z godności i podważające poczucie ich wartości. Ustawodawca wprowadził w art. 55a ustawy o IPN karę alternatywną w postaci grzywny lub karę do 3 lat pozbawienia wolności. Zarówno rodzaj kary, jak i dolny oraz górny próg sankcji wyznaczony jest charakterem dobra chronionego oraz rozmiarem szkodliwości czynów zabronionych i należy ocenić je pozytywnie z punktu widzenia konieczności w państwie demokratycznym. Jest to rozwiązanie nawiązujące do zakresu kar przewidzianych za przestępstwa o podobnym charakterze, unormowanych w obowiązującym art. 55 ustawy o IPN (tzw. kłamstwo oświęcimskie) i art. 133 k.k. (znieważanie Narodu lub Rzeczypospolitej Polskiej). Zaznaczyć należy, że wysokość kary za przestępstwa określone we wskazanych artykułach nie budziła dotychczas wątpliwości.

Dolegliwość kary przewidzianej w art. 55a ustawy o IPN jest uzależniona od stopnia szkodliwości czynu, co daje pewną elastyczność w zakresie orzekania 
o wymiarze kary (kara grzywny lub kara 3 lat pozbawienia wolności). Kwestionowany przepis nie przewiduje jedynie kary pozbawienia wolności, lecz również karę grzywny. Nie nakazuje więc automatycznego wymierzania kary pozbawienia wolności. Ponadto, przepisy Kodeksu karnego określają szeroki katalog narzędzi pozwalający sądowi w uzasadnionych przypadkach na modyfikację kary. Jak bowiem trafnie podkreśla się w nauce prawa karnego, ustawodawca kary nie wymierza. Ustawodawca - za pomocą sankcji oraz rozmaitych instytucji części ogólnej Kodeksu karnego - zakreśla jedynie ramy, w jakich wymiaru takiego dokonuje sąd (zob. Z. Ćwiąkalski, O niektórych pojęciach związanych z wymiarem kary, „Nowe Prawo” 1989, nr 4, s. 41). Ustalenie granic ustawowego zagrożenia karą powinno uwzględniać przykładowo alternatywę przewidzianą w art. 37a k.k. w postaci możliwości orzeczenia kary grzywny albo kary ograniczenia wolności zamiast kary pozbawienia wolności. Jak podkreśla się w piśmiennictwie, przepis ten ewidentnie poszerza luz decyzyjny poprzez umożliwienie orzeczenia kar nieizolacyjnych zamiast kary pozbawienia wolności o granicy nieprzekraczającej 8 lat, jednocześnie całkowicie „milczy” na temat racjonalizujących go okoliczności lub uwarunkowań (zob. J. Giezek, O sankcjach alternatywnych oraz możliwości wyboru rodzaju wymierzanej kary, „Palestra” 2015, nr 7-8, s. 27 i 29). Podobny cel będą realizowały: art. 59 k.k., dający podstawę do odstąpienia od wymierzenia kary, oraz art. 66 k.k., umożliwiający warunkowe umorzenie postępowania. Należy zatem uznać, że kara przewidziana w art. 55a ustawy o IPN obowiązująca $\mathrm{w}$ przedstawionym otoczeniu normatywnym nie jest środkiem zbyt silnie ingerującym w wolności i prawa człowieka w stosunku do stopnia naruszenia dobra chronionego kwestionowanym przepisem. Związek pomiędzy wagą czynów mieszczących się w opisie ustawowym a sankcją karną w sposób proporcjonalny wyraża społeczną szkodliwość czynów zabronionych w art. 55a ustawy o IPN.

Wysokość zagrożenia karą, jaką określa art. 55a ustawy o IPN, nie odbiega ponadto od międzynarodowych standardów penalizacji podobnych typów zachowań. Wprawdzie przestępstwo błędnego przypisywania odpowiedzialności za zbrodnie przeciwko pokojowi, ludzkości i zbrodnie wojenne nie ma odpowiednika w państwach Rady Europy, niemniej można wskazać unormowania odnoszące się do innych form tzw. kłamstwa historycznego, w tym penalizujące minimalizowanie wymienionych zbrodni. Przykładowo, przepisy karne odnoszące się do wyrażania w określonych formach pewnych poglądów na niektóre wydarzenia historyczne zawarte są w niemieckim kodeksie karnym ( $\$ 130$ ust. 3 i 4 Strafgesetzbuch [w:] Juris, Bundesministerium der Justiz und für Verbraucherschutz, https://www.gesetze-im-internet.de/stgb/; tłumaczenie: BAS-ZSP 568/18). Odpowiedzialności karnej podlega ten, kto aprobuje czyn z rodzaju określonego w paragrafie 6 ust. 1 kodeksu międzynarodowego prawa karnego popełniony pod panowaniem narodowego socjalizmu, zaprzecza mu lub go bagatelizuje, podlega karze pozbawienia wolności na okres do 5 lat lub karze grzywny. W Austrii zgodnie z tzw. ustawą o zakazie z 1947 r. rozwiązano NSDAP 
i wszystkie związane z nią organizacje, zakazując ich ponownego powoływania oraz prowadzenia działalności inspirowanej przez narodowy socjalizm. Prowadzenie takiej działalności i/lub zaprzeczanie narodowosocjalistycznemu ludobójstwu lub innym narodowosocjalistycznym zbrodniom przeciwko ludzkości, podlega karze pozbawienia wolności na okres od 1 roku do 10 lat, a w przypadku, gdy sprawca lub czyn jest szczególnie niebezpieczny, do 20 lat (Rechtsinformationssystem, Bundeskanzleramt, Verbotsgesetz, $\$ 3 \mathrm{~g}$, https://www.ris.bka. gv.at/Dokumente/Erv/ERV_1945_13/ERV_1945_13.pdf; tłumaczenie: BAS-ZSP 568/18). W Belgii zgodnie z ustawą z 1995 r. zaprzeczanie, minimalizowanie, usprawiedliwianie lub aprobowanie ludobójstwa popełnionego podczas II wojny światowej przez niemiecki reżim narodowosocjalistyczny podlega karze pozbawienia wolności od 8 dni do 1 roku oraz karze grzywny. W Czechach zgodnie z kodeksem karnym z 2009 r. zaprzeczanie, podawanie w wątpliwość, pochwalanie lub usprawiedliwianie nazistowskiego lub komunistycznego ludobójstwa lub zbrodni przeciw ludzkości podlega karze pozbawienia wolności od 6 miesięcy do 3 lat (strona internetowa Światowej Organizacji Własności Intelektualnej (WIPO), http://www.wipo.int/wipolex/en/text.jsp?file_id=248531, „Zakon ze dne 8. ledna 2009 trestní zákoník"; nieoficjalne angielskie tłumaczenie czeskiego kodeksu karnego dostępne jest na stronie Europejskiej Sieci Szkolenia Kadr Wymiaru Sprawiedliwości (EJTN), http://www.ejtn.eu/PageFiles/6533/Criminal\%20Code\% 20of\%20the\%20Czech\%20Republic.pdf, „Criminal Code of the Czech Republic”; tłumaczenie: BAS-ZSP 568/18). We Francji zgodnie z ustawą z 1990 r. o zniesieniu wszelkich form aktów rasistowskich, antysemickich bądź ksenofobicznych, każdy, kto kwestionuje istnienie jednego lub więcej przestępstw przeciwko ludzkość tak, jak są one określone w art. 6 statutu Międzynarodowego Trybunału Wojskowego, załączonego do układu londyńskiego z 8 sierpnia 1945 r., popełnionych przez członków organizacji uznanych za przestępcze zgodnie $\mathrm{z}$ art. 9 tego statutu lub przez osobę uznaną za winną takich przestępstw przez francuską lub międzynarodową jurysdykcję, podlega karze od 1 miesiąca do 1 roku pozbawienia wolności lub grzywny. Na Węgrzech, zgodnie z przyjętą w 2010 r. nowelizacją kodeksu karnego z 1978 r., publiczne zaprzeczanie ludobójstwu lub innym zbrodniom przeciwko ludzkości popełnionym przez system narodowosocjalistyczny i system komunistyczny, podawanie ich w wątpliwość lub pomniejszanie, podlega karze pozbawienia wolności do 3 lat (http://www. parlament.hu/irom39/00025/00025.pdf; tłumaczenie: BAS-ZSP 568/18). Podobny przepis obowiązuje w Izraelu, który penalizuje karą pozbawienia wolności do lat 5. Kryminalizacji podlega publikowanie jakiegokolwiek stwierdzenia zaprzeczającego lub pomniejszającego rozmiary czynów popełnionych w okresie reżimu nazistowskiego, będących zbrodniami przeciwko narodowi żydowskiemu lub zbrodniami przeciwko ludzkości, z zamiarem bronienia sprawców tych czynów lub wyrażając sympatię bądź utożsamiając się z nimi (Denial of Holocaust-Prohibition-Law 5746-1986 z 8 lipca 1986 r.; tłumaczenie: BAS-ZSP 568/18). 
W świetle powyższego, należy stwierdzić, że sankcja zastosowana w art. 55a ustawy o IPN nie narusza zasady proporcjonalności wynikającej z art. 42 ust. 1 w związku z art. 31 ust. 3 Konstytucji.

5. Zdaniem wnioskodawcy rozszerzenie zakresu penalizacji art. 55a ustawy o IPN o czyny popełnione nieumyślnie może rodzić obawy o skutki wypowiedzi publicznych lub innych form przekazu publicznego na temat wydarzeń historycznych. Zarzut ten wnioskodawca postawił w kontekście zasady określoności przepisu karnego i ewentualnych trudności, jakie rodzi, jego zdaniem, ocena zachowania przez sprawcę reguł ostrożności wymaganych w danych okolicznościach oraz ustalenie, czy sprawca przewidywał albo mógł przewidzieć, że publicznie i wbrew faktom przypisuje Narodowi Polskiemu lub Państwu Polskiemu odpowiedzialność lub współodpowiedzialność za zbrodnie określone w art. 55a ustawy o IPN.

Zauważyć należy, że w stanie prawnym przed wejściem w życie kwestionowanego przepisu prawnokarnie nieuchwytne pozostawały wypowiedzi z użyciem „polskie obozy koncentracyjne”, uzasadniane przez autorów ex post intencją wskazania na położenie tych obozów poza granicami Niemiec, nie zaś przypisywanie Narodowi Polskiemu bądź Państwu Polskiemu sprawstwa ich utworzenia i popełnianych $\mathrm{w}$ nich zbrodniach ludobójstwa. Poszerzenie znamion strony podmiotowej czynu z art. 55a wynika, jak wskazuje w uzasadnieniu projektodawca, z obowiązku zachowania wymaganej w danych okolicznościach ostrożności oraz przewidywania konsekwencji posługiwania się nieprawdziwymi stwierdzeniami. Zgodnie bowiem z art. $9 \$ 2$ k.k. czyn zabroniony popełniony jest nieumyślnie, jeżeli sprawca nie mając zamiaru jego popełnienia, popełnia go jednak na skutek niezachowania ostrożności wymaganej w danych okolicznościach. Inaczej rzecz ujmując, przesłanką odpowiedzialności za przestępstwo nieumyślne jest naruszenie zasad ostrożności odnoszących się do danego działania, natomiast między tym naruszeniem zasad ostrożności, a końcowym rezultatem działania zachodzi związek przyczynowy. Formami winy nieumyślnej są: lekkomyślność, gdy sprawca świadomie narusza zasady ostrożności, przewiduje możliwość popełnienia czynu, lecz przypuszcza, że go uniknie, oraz niedbalstwo, gdy sprawca możliwości popełnienia czynu zabronionego nie przewiduje, chociaż powinien i mógł to przewidzieć. Jeżeli natomiast w ogóle nie można przypisać sprawcy zawinionego działania, to znaczy jeżeli występują ustalone ustawowo okoliczności wyłączające winę, takie jak: niepoczytalność, czyli niemożność rozpoznania znaczenia swojego czynu, błąd co do faktu, nieświadomość bezprawności czynu, rozkaz przełożonego. Wówczas przestępność czynu jest wykluczona (brak przestępstwa), a wedle zasady nullum crimen sine culpa, sprawca nie może podlegać karze. Jedynie zawiniony czyn sprawcy może być karany. Artykuł 53 k.k. zawiera dyrektywę stopnia winy, stwierdzając, że dolegliwość kary nie może przekraczać stopnia winy sprawcy. Najwyższy stopień winy odpowiada górnemu pułapowi kary przewidzianej za dane przestępstwo przewidziane przez konkretny przepis. 
Ustawodawca w art. 55a ust. 2 ustawy o IPN złagodził sankcję odpowiednio do stopnia społecznej szkodliwości tego występku, przewidując karę grzywny bądź alternatywnie karę ograniczenia wolności. Dla oceny zachowań zakazanych przez art. 55a ustawy o IPN oraz stopnia winy ostatecznie decydujące powinny być przede wszystkim okoliczności konkretnej sprawy i okoliczności działania sprawcy. Warto dodać, że tutaj również będą miały zastosowanie przewidziane w przepisach Kodeksu karnego mechanizmy pozwalające sądowi w uzasadnionych przypadkach na modyfikację kary. Przypomnieć należy, że wnioskodawca nie kwestionuje zasadności penalizacji nieumyślnego, publicznego popełnienia czynu zabronionego $\mathrm{w}$ art. 55a ustawy o IPN. Wskazuje natomiast na konsekwencje zastosowania pojęć nieostrych i ocennych, powodujących trudności w przypisaniu winy nieumyślnej. Jak zostało wykazane, stopień niedookreśloności tych pojęć nie osiąga poziomu, który uniemożliwiałby wyznaczenie znamion typu czynu zabronionego. W związku z poczynionymi ustaleniami za nieuprawnione należy uznać twierdzenie, że karalność nieumyślnego popełnienia tego czynu narusza zasadę określoności przepisu karnego.

\section{- 2. Analiza zgodności art. 55a ustawy o IPN z art. 54 ust. 1 w związku z art. 31 ust. 3 Konstytucji}

Ustalenia poczynione podczas analizy zarzutu pierwszego pozwalają stwierdzić, że pojęcia użyte dla określenia strony przedmiotowej przestępstwa opisanego w art. 55a ustawy o IPN nie naruszają wymogu dostatecznej określoności regulacji prawnej i tym samym nie wpływają negatywnie na swobodę wyrażania poglądów. Należy zatem rozpatrzeć kwestię, czy ograniczenia nakładane przez skarżony przepis stanowią proporcjonalne ograniczenie wolności wyrażania poglądów. Penalizacja publicznych wypowiedzi, które wbrew faktom przypisują Narodowi Polskiemu lub Państwu Polskiemu odpowiedzialność lub współodpowiedzialność za zbrodnie określone w art. 55a ustawy o IPN, niewątpliwie stanowi ingerencję w wolność wyrażania poglądów, wolność pozyskiwania informacji oraz wolność rozpowszechniania informacji, gwarantowaną w art. 54 ust. 1 Konstytucji. Ingerencja ta jest jednak dopuszczalna w granicach wyznaczonych w art. 31 ust. 3 Konstytucji, który stanowi wzorzec kontroli wprowadzanych przez ustawodawcę ograniczeń wyrażania poglądów. Artykuł ten formułuje kumulatywnie ujęte przesłanki dopuszczalności ograniczeń, które oprócz spełnienia formalnego kryterium ustanowienia w ustawie, nie mogą naruszać istoty wolności, muszą być przydatne, konieczne (niezbędne) i proporcjonalne w kontekście założonego celu regulacji, a także muszą być uzasadnione co najmniej jedną przesłanką materialną. Jak wynika z orzecznictwa Trybunału Konstytucyjnego, na mocy Konstytucji zakazane jest propagowanie niektórych treści z samej istoty niemieszczących się „w aksjologii demokratycznej przestrzeni prawnej”. Chodzi tu np. o treści wyrażające nienawiść rasową i narodowościową, propagujące totalitaryzm, wzywające do przemocy w celu zdobycia władzy (zob. wyroki TK z: 
11 października 2006 r., sygn. akt P 3/06; 21 września 2015 r., sygn. akt K 28/13). W kwestii dopuszczalnych ograniczeń wolności słowa motywowanych dążeniem do ochrony autorytetu państwa i jego organów, wypowiedział się Trybunał w wyroku z 6 lipca 2011 r. (sygn. akt P 12/09), w którym orzekł o zgodności art. 135 $\$ 2$ k.k. z art. 54 ust. 1 w związku z art. 31 ust. 3 Konstytucji. Stwierdził wówczas, że „ochrona państwa polskiego zajmuje pierwszoplanową pozycję” w Kodeksie karnym, a „ochrona tej wartości jest ochroną wspólnoty w postaci państwa jako organizacji narodu, społeczeństwa i stanowi logiczne prius w stosunku do gwarancji realizacji wszystkich pozostałych wartości”.

Na tym tle należy zatem ocenić ograniczenie wolności wyrażania poglądów, wynikające $\mathrm{z}$ art. 55a ustawy o IPN, który nakazuje uznać za bezprawne zachowania polegające na publicznym i wbrew faktom przypisywaniu Narodowi Polskiemu lub Państwu Polskiemu odpowiedzialność lub współodpowiedzialność za popełnione przez III Rzeszę Niemiecką zbrodnie nazistowskie określone w art. 6 Karty Międzynarodowego Trybunału Wojskowego lub za inne przestępstwa stanowiące zbrodnie przeciwko pokojowi, ludzkości lub zbrodnie wojenne lub w inny sposób rażąco pomniejszające odpowiedzialność rzeczywistych sprawców tych zbrodni. W pierwszej kolejności należy wskazać na dobro prawne, które uzasadnia prawnokarną ingerencję w wolność wypowiedzi. Ustalenia co do przedmiotu ochrony zostały już poczynione w części analizy dotyczącej zarzutu naruszenia art. 42 ust. $1 \mathrm{w}$ związku z art. 2 oraz w związku z art. 31 ust. 3 Konstytucji. W tym miejscu można ograniczyć się do przypomnienia, że ustanowiona w art. 55a ustawy o IPN penalizacja ma służyć ochronie godności Narodu Polskiego i Państwa Polskiego, czyli tę sferę wartości, która wiąże się z przynależnością jednostki do polskiej wspólnoty narodowej, z uczestnictwem w ciągłości tej wspólnoty, z tożsamością narodową, warunkowaną także zbiorową pamięcią i godnością osobistą. Naruszenie godności narodowej stanowi zarazem naruszenie dobra zbiorowego oraz dobra indywidualnego, wynikającego z poczucia przynależności do danej wspólnoty narodowej. Przypisywanie wbrew faktom zbrodni, o których mowa w art. 55a ustawy o IPN, Narodowi lub Państwu Polskiemu bądź też pomniejszanie odpowiedzialności rzeczywistych ich sprawców stanowi pomówienie, mogące godzić nie tylko w cześć oraz godność narodową i państwową, ale może również naruszyć dobro prawne o charakterze osobistym. O potrzebie zastosowania prawnokarnych środków w celu ochrony tego dobra była mowa w części, dotyczącej zarzutu proporcjonalności sankcji z art. 55a ustawy o IPN. Ustalenia tam poczynione zachowują swoją aktualność również w kontekście oceny proporcjonalności ograniczenia wolności wypowiedzi. Zauważyć należy, że ochrona dobra z art. 55a ustawy o IPN skutkuje ograniczeniem wolności wypowiedzi jedynie w zakresie wypowiedzi niemającej pokrycia w faktach. Kryminalizacja czynów zabronionych w skarżonym przepisie nie zakazuje publicznych wypowiedzi, w tym także prowadzenia działalności twórczej o profilu artystycznym czy naukowym, mających za przedmiot prawdę historyczną nawet 
w najbardziej niechlubnych odsłonach. Zakazuje natomiast stawiania publicznie nieprawdziwych tez wskazujących na odpowiedzialność Narodu Polskiego lub Państwa Polskiego za zbrodnie popełnione w czasie II wojny światowej (zob. P. Palka, Zakres penalizacji art. 55a, op. cit., s. 21). Penalizacja takich zachowań jest zatem formą ochrony przed zniesławieniem w szczególnej postaci. Zniesławienie jest działaniem penalizowanym w Kodeksie karnym (art. 212 k.k.), z tą jednak różnicą, że dobro chronione tym przepisem ma charakter wyłącznie indywidualny. Poza zakresem ochrony pozostaje godność w znaczeniu zbiorowym. $\mathrm{Z}$ punktu widzenia uregulowanej $\mathrm{w}$ art. 31 ust. 3 Konstytucji przesłanki konieczności ograniczeń korzystania z wolności wyrażania poglądów należy przyjąć, że penalizacja przewidziana $\mathrm{w}$ art. 55a ustawy o IPN jest uzasadniona.

Wartość dobra chronionego w art. 55a ustawy o IPN oraz społeczna szkodliwość jego naruszenia nie jest jedynym kryterium oceny zagrożeń karnych $\mathrm{w}$ nim przyjętych. Ocena z punktu widzenia zasady proporcjonalności powinna ponadto uwzględniać instrumenty umożliwiające modyfikację kary. Należy przypomnieć, że weryfikacja w tym względzie powinna brać pod uwagę możliwość zastosowania art. 37a k.k. w postaci orzeczenia kary grzywny albo kary ograniczenia wolności zamiast kary pozbawienia wolności, art. 59 k.k. dającego podstawę do odstąpienia od wymierzenia kary czy art. 66 k.k. umożliwiającego warunkowe umorzenie postępowania.

Wreszcie należy odnieść się do ustanowionego w art. 55a ust. 3 ustawy o IPN kontratypu działalności artystycznej i naukowej. Przesądza on o tym, że kryminalizacja czynów zabronionych w art. 55a ust. 1 i 2 ustawy o IPN nie ma charakteru bezwzględnego. Dostrzegając kolizję dóbr leżących u podstaw wskazanych czynów zabronionych oraz działalności artystycznej i naukowej, ustawodawca wyłącza z zakresu bezprawności działania podejmowane w ramach aktywności artystycznej czy naukowej. Wolność twórcza, w tym przede wszystkim prowadzenie badań naukowych, oznacza bowiem także prawo do błędu, fałszywości teorii naukowych czy choćby luk w ustaleniach badawczych (zob. C. Starck, Wolność badań naukowych i jej granice, „Przegląd Sejmowy” 2007, nr 3, s. 45 i n.). Oznacza to, że o ile opis czynów zabronionych w art. 55a ust. 1 i 2 ustawy o IPN ogranicza wolność wypowiedzi do swobody wypowiadania tez „zgodnych z prawdą”, ponieważ zakazuje publicznego, „wbrew prawdzie” przypisywania odpowiedzialności Narodowi Polskiemu i Państwu Polskiemu zbrodni totalitarnych oraz umniejszania odpowiedzialności ich rzeczywistych sprawców, o tyle art. 55a ust. 3 ustawy o IPN legalizuje wszystkie tego typu tezy, jeżeli zostały wyartykułowane w działalności naukowej, to znaczy pozyskane zostały w sposób metodyczny, sprawdzalny i mający na celu poznanie prawdy (zob. P. Palka, Zakres penalizacji art. 55a, op. cit., s. 21). Zarzut nadmiernej i nieproporcjonalnej ingerencji w wolność wypowiedzi, prowadzącej do „efektu mrożącego”, odstraszającego od udziału w debacie publicznej i prowadzeniu badań naukowych należy zatem uznać za nieuzasadniony. 


\section{- 3. Analiza zgodności art. 1 pkt 1 lit. a tiret trzecie oraz art. 2a ustawy o IPN z art. 42 ust. 1 w związku z art. 2 i w związku z art. 31 ust. 3 Konstytucji}

1. Na mocy art. 1 pkt 2 ustawy nowelizującej o IPN poszerzony został zakres przedmiotowy spraw (art. 1 pkt 1 lit. a ustawy o IPN), w których wszczynane są śledztwa dotyczące przestępstw z art. 55 ustawy o IPN. Artykuł 55 ustawy o IPN odnosi się do tzw. przestępstwa negacjonizmu, a do czasu wejścia w życie ustawy nowelizującej o IPN określanego przestępstwem „kłamstwa oświęcimskiego". Polega ono na publicznym i wbrew faktom zaprzeczaniu zbrodniom, wskazanych w art. 1 pkt 1 ustawy o IPN. W powołanym przepisie mowa jest o czterech kategoriach zbrodni: nazistowskich, komunistycznych, ukraińskich nacjonalistów i członków ukraińskich formacji kolaborujących z III Rzeszą Niemiecką oraz innych przestępstw stanowiących zbrodnie przeciwko pokojowi, ludzkości lub zbrodnie wojenne. Zbrodnie ukraińskich nacjonalistów i członków ukraińskich formacji kolaborujących z III Rzeszą Niemiecką zostały zdefiniowane w art. 2a ustawy o IPN jako czyny popełnione przez ukraińskich nacjonalistów w latach 1925-1950, polegające na stosowaniu przemocy, terroru lub innych form naruszania praw człowieka wobec jednostek lub grup ludności. Zbrodnią ukraińskich nacjonalistów i członków ukraińskich formacji kolaborujących z III Rzeszą Niemiecką jest również udział w eksterminacji ludności żydowskiej oraz ludobójstwie na obywatelach II Rzeczypospolitej na terenach Wołynia i Małopolski Wschodniej. Wątpliwości wnioskodawcy koncentrują się na użytych we wskazanych przepisach terminach „ukraińscy nacjonaliści” oraz „Małopolska Wschodnia”. W jego ocenie, brak precyzyjnego zdefiniowania tych pojęć wpływa na niemożność zidentyfikowania znamion czynu zabronionego w art. 55 ustawy o IPN, i tym samym narusza konstytucyjną zasadę określoności czynu zabronionego.

„Małopolska Wschodnia” to nazwa używana w nomenklaturze oficjalnej od wczesnych lat dwudziestych XX wieku, głównie po roku 1923, przede wszystkim w administracji i prawodawstwie. Miała ona zastąpić dawną, obcojęzyczną nazwę „Galicja” oraz usankcjonować nowy podział terytorialny tych ziem po reformie administracyjnej z 1920 r., a przede wszystkim podkreślić wyłącznie „polski” charakter tego terytorium (zob. K. Hibel, Od „Małopolski Wschodniej” do „Ukrainy Zachodniej”. Geneza, rozwój oraz zakres funkcjonowania w języku polskim nazw geograficznych odnoszących się do „Galicji Wschodniej” w latach 1918-1939, „Slavia Orientalis” 2012, t. LXI, nr 4, s. 492). W jej skład wchodziły trzy województwa: lwowskie, stanisławowskie i tarnopolskie, utworzone na podstawie ustawy z dnia 3 grudnia 1920 r. o tymczasowej organizacji władz administracyjnych II instancji (województw) na obszarze b. Królestwa Galicji i Lodomerji z W. Ks. Krakowskiem oraz na wchodzących w skład Rzeczypospolitej Polskiej obszarach Spisza i Orawy (Dz. U. Nr 117, poz. 768); (zob. Małopolska Wschodnia [w:] Encyklopedja podręczna prawa publicznego (konstytucyjnego, administracyj- 
nego i międzynarodowego), red. Z. Cybichowski, t. I, Warszawa 1930, s. 434; J. Haliczer, Małopolska [w:] Encyklopedja nauk politycznych (zagadnienia społeczne, polityczne i gospodarcze), t. III, red. E.J. Reyman, Warszawa 1938, s. 858; T. Prus-Faszczewski, Małopolska Wschodnia a zagadnienie obronności państwa, Warszawa 1939, s. 2; A. Podraza, Europa. Galicja. Regiony. Pisma historyczne, Kraków 2006, s. s. 76-77; J. Sał, Galicja Wschodnia [w:] Encyklopedia historii Polski. Dzieje polityczne, t. 1, Warszawa 1994, s. 188). Termin „Małopolska Wschodnia” stosowany był w literaturze polskiego prawa administracyjnego, czego przykładem jest książka Kazimierza Władysława Kumanieckiego, profesora Uniwersytetu Jagiellońskiego, Bohdana Wasiutyńskiego, profesora Uniwersytetu Warszawskiego, oraz Jerzego Panejki, profesora Uniwersytetu Stefana Batorego, w której użyto terminu: „Województwa wschodniej Małopolski” (zob. K.W. Kumaniecki, B. Wasiutyński, J. Panejko, Polskie prawo administracyjne w zarysie, Kraków 1929, s. 187-189; R. Jastrzębski, Opinia prawna - zakres pojęciowy terminów Wołynia i Małopolski Wschodniej w związku z ustawa z dnia 26 stycznia 2018 r. o zmianie ustawy o Instytucie Pamięci Narodowej - Komisji Ścigania Zbrodni przeciwko Narodowi Polskiemu, ustawy o grobach i cmentarzach wojennych, ustawy o muzeach oraz ustawy o odpowiedzialności podmiotów zbiorowych za czyny zabronione pod groźbą kary, BAS 540/18, s. 7). Nazwy „Małopolska Wschodnia” używano także $\mathrm{w}$ wydawnictwach związanych $\mathrm{z}$ administracją państwową czy też wydawanych przez instytucje z państwem związane, na przykład w dziedzinie turystyki, informacji gospodarczej czy wojskowości, szczególnie bezpieczeństwa państwa (zob. K. Hibel, Od „Małopolski Wschodniej”, op. cit., s. 494).

Po napaści III Rzeszy Niemieckiej na II Rzeczpospolitą, a w 1941 r. na ZSRR, obszar Małopolski Wschodniej, obejmujący trzy województwa państwa polskiego, oraz Wołyń - dawne województwo wołyńskie, był okupowany przez ówczesne państwo niemieckie. Następnie w latach 1943-1944 stał się terenem akcji eksterminacyjnych nacjonalistów ukraińskich przede wszystkim wobec ludności polskiej (zob. W. Bonusiak, Małopolska Wschodnia pod rządami Trzeciej Rzeszy, Rzeszów 1990; Antypolska akcja nacjonalistów ukrainskich w Małopolsce Wschodniej w świetle dokumentów Rady Głównej Opiekuńczej 1943-1944, wstęp i oprac. L. Kulińska, A. Roliński, Kraków 2003).

Współcześnie pojęcie Małopolski Wschodniej i Wołynia jest przedmiotem badań przede wszystkim historyków, zwłaszcza w związku z eksterminacją ludności polskiej na tym obszarze (szerzej zob. Kwestia ukraińska i eksterminacja ludności polskiej w Małopolsce Wschodniej w świetle dokumentów Polskiego Państwa Podziemnego 1942-1944, wstęp i oprac. L. Kulińska, A. Roliński, Kraków 2004; G. Hryciuk, Przemiany narodowościowe i ludnościowe w Galicji Wschodniej i na Wołyniu w latach 1931-1948, Toruń 2005; Kościół Rzymskokatolicki i Polacy w Małopolsce Wschodniej podczas wojny ukrainsko-polskiej 1918-1939. Źródła, oprac., wstęp, przypisy, indeksy i wybór fotografii J. Wołczański, t. I, II, Lwów-Kraków 2012; Małopolska Wschodnia. Nasza historia, nasza pamięć, cz. 4, 
Kraków 2014; T.J. Kotliński, Towarzystwo Galicyjskich Kandydatów Notarialnych Wschodniej Małopolski we Lwowie (1889-1939), „Rejent” 2009, nr 3). Administracyjnie zaś obszar ten obejmuje w zasadzie trzy południowowschodnie województwa państwa polskiego w granicach sprzed 1 września 1939 r. (województwa: lwowskie, tarnopolskie oraz stanisławowskie), a także graniczące z dwoma pierwszymi województwo wołyńskie (zob. R. Jastrzębski, Opinia prawna - zakres pojęciowy terminów Wołynia i Małopolski Wschodniej, op. cit., s. 8; szerzej zob. G. Zamoyski, Zmiany podziałów administracyjnych na terenie województw południowych w latach 1918-1939 [w:] Historia. Archiwistyka. Ludzie. Ksiega pamiątkowa w pięćdziesiąta rocznice powołania Archiwum Państwowego w Rzeszowie, Warszawa-Rzeszów 2000).

Zgodnie z „Małym Rocznikiem Statystycznym” z 1939 r. (zob. „Mały Rocznik Statystyczny 1939”, s. 13-14) poszczególne województwa liczyły:

- lwowskie, składające się z 27 powiatów - 28402 km²,

- stanisławowskie, składające się z 12 powiatów - 16894 km²,

- tarnopolskie, składające się z 17 powiatów - $16533 \mathrm{~km}^{2}$.

W związku z tym, mimo braku legalnej definicji Małopolski Wschodniej, należy uznać, że jej obszar pokrywał się z obszarem wyżej wymienionych trzech województw. Warto zaznaczyć, że pojęcie Małopolski Zachodniej oraz Małopolski Wschodniej zostało użyte w rozporządzeniu Ministra Aprowizacji i Ministra Rolnictwa i Dóbr Państwowych w przedmiocie obrotu zbożem siewnem w roku gosp. 1920/21 (Dz. U. Nr 66, poz. 444) bez określenia jednak właściwego obszaru.

Na uwagę zasługuje także używanie tego pojęcia w judykaturze Sądu Najwyższego w latach 1926-1938 (zob. uchwała SN z 10 października 1926 r., sygn. akt Nd 14/26, LEX nr 1631840; wyroki SN z: 27 kwietnia 1931 r., sygn. akt II K 154/31; 18 października 1934 r., sygn. akt. II K 1081/34; orzeczenia SN z: 19 maja 1928 r., sygn. akt Rw. 2483/27; 27 czerwca 1930 r., sygn. akt III Rw 2563/29, LEX nr 1670201; 26 stycznia 1931 r., sygn. akt II K 1056/30, LEX nr 1626675; 29 października 1931 r., sygn. akt II K 800/31, LEX nr 1627174; 14 stycznia 1932 r., sygn. akt II K 1131/31, LEX nr 1627347; 20 października 1938 r., sygn. akt II K 856/38, LEX nr 1628234), a także w postępowaniu patentowym (zob. orzeczenie Wydziału Odwoławczego Urzędu Patentowego z dnia 30 października 1928 r. Odw. 712/27, LEX nr 64381).

Współcześnie pojęcie Małopolski Wschodniej było stosowane w orzecznictwie Sądu Najwyższego oraz wojewódzkich sądów administracyjnych w sprawach z zakresu uprawnień kombatanckich oraz świadczeń pieniężnych z tytułu pracy przymusowej (zob. uchwała SN z 3 kwietnia 1996 r., sygn. akt III AZP 37/95; wyrok WSA w Opolu z 24 stycznia 2005 r., sygn. akt II SA/Op 414/04, LEX nr 816358; wyrok WSA w Poznaniu z 18 grudnia 2007 r., sygn. akt IV SA/ Po 665/07, LEX nr 983128). Ponadto pojęcie Małopolski Wschodniej znalazło się w komunikacie nr 17 Ministra Nauki i Szkolnictwa Wyższego z dnia 6 sierp- 
nia 2009 r. o przyznanych środkach finansowych na działalność wspomagającą badania w 2008 r. na rzecz Towarzystwa Naukowego Katolickiego Uniwersytetu Lubelskiego Jana Pawła II (Dz. Urz. MNiSW 2009, nr 4, poz. 73; załącznik, liczba porządkowa 977).

W związku z tym należy stwierdzić, że ustawodawca, posługując się w art. 2a ustawy o IPN terminem Małopolska Wschodnia, spełnił wymóg dostatecznej określoności przepisów represyjnych. Pojęcie to bowiem ma ugruntowane znaczenie i obejmuje obszar trzech województw państwa polskiego sprzed wybuchu drugiej wojny światowej.

2. Ustawodawca nie definiuje pojęcia „ukraińscy nacjonaliści” w kontekście zakresu podmiotowego zbrodni, którym zaprzeczanie jest kryminalizowane w art. 55 ustawy o IPN. Zbrodnie ukraińskich nacjonalistów (oraz członków ukraińskich formacji kolaborujących z III Rzeszą Niemiecką) definiuje w art. 2a ustawy o IPN poprzez wskazanie czynności sprawczej i są to czyny popełnione przez ukraińskich nacjonalistów w latach 1925-1950, polegające na stosowaniu przemocy, terroru lub innych form naruszania praw człowieka wobec jednostek lub grup ludności, oraz udział w eksterminacji ludności żydowskiej oraz ludobójstwie na obywatelach II Rzeczypospolitej na terenach Wołynia i Małopolski Wschodniej. Na marginesie rozważań można wskazać, że w odniesieniu do innej kategorii zbrodni, o której mowa w art. 1 pkt 1 lit. a ustawy o IPN, zbrodni nazistowskich, ustawodawca nie podaje żadnej definicji legalnej tego pojęcia. Na podstawie ustawy o IPN nie można wskazać ani czynności sprawczej, ani strony podmiotowej czynu zabronionego. Niemniej dotychczas nie były podnoszone wątpliwości doktryny co do znamion typu czynu zabronionego.

Pojęcie „ukraiński nacjonalista” oznacza osobę związaną z nacjonalizmem ukraińskim - ruchem politycznym powstałym w pierwszej połowie XIX wieku. Ideologia ukraińskiego nacjonalizmu reprezentowana była przede wszystkim przez Organizację Ukraińskich Nacjonalistów (dalej: OUN) oraz późniejszą Ukraińską Powstańczą Armię (dalej: UPA), których działalność została opisana przez badaczy historii (zob. T. Dąbkowski, Ukrainski ruch narodowy 1912-1923, Warszawa 1985; W. Siemaszko, E. Siemaszko, Ludobójstwo dokonane przez nacjonalistów ukraińskich na ludności polskiej Wołynia 1939-1945, t. I i II, Warszawa 2000; G. Mazur, J. Skwara, J. Węgierski, Kronika 2350 dni wojny i okupacji Lwowa 1 IX 1939 - 5 II 1946, Katowice 2007; G. Motyka, D. Libionka, Antypolska akcja OUN-UPA 1943-1944. Fakty i interpretacje, seria „Konferencje IPN” t. 4, Warszawa 2002; G. Motyka, Postawy wobec konfliktu polsko-ukraińskiego w latach 1939-1953 w zależności od przynależności etnicznej, państwowej i religijnej [w:] Tygiel narodów. Stosunki społeczne i etniczne na dawnych ziemiach wschodnich Rzeczypospolitej, red. K. Jasiewicz, Warszawa/Londyn 2002; idem, Ukrainska partyzantka 1942-1960, Warszawa 2006; idem, Od rzezi wołyńskiej do akcji „Wisła”. Konflikt polsko-ukraiński 1943-1947, Kraków 2011; W. Bonusiak, Wołyń podczas II wojny światowej (konflikty narodowościowe) [w:] Historia i dziedzictwo regio- 
nów w Europie Środkowo-Wschodniej w XIX i XX w., red. M. Stolarczyk, A. Kawalec, J. Kuźnicki, Rzeszów 2011). Prowadziły one walkę przeciwko wrogom Ukrainy, która w praktyce koncentrowała się między innymi na działaniach antypolskich zmierzających do masowej eksterminacji ludności polskiej zamieszkującej tereny Wołynia i Małopolski Wschodniej (zob. W. Bonusiak, Wołyń podczas II wojny światowej, op. cit., s. 129).

Rozwój ukraińskiego ruchu nacjonalistycznego zintensyfikował się po przegranej wojnie z Polską w latach 1918-1919, kiedy część oficerów Ukraińskiej Armii Halickiej niepogodzona z przegraną powołała do życia terrorystyczną i sabotażową Ukraińską Organizację Wojskową (dalej: UOW); (zob. R. Wysocki, Organizacja Ukraińskich Nacjonalistów w Polsce w latach 1929-1939, Lublin 2003, s. 41-47; G. Motyka, Ukraińska partyzantka, op. cit., s. 36-38 i 42). Ukraińska Organizacja Wojskowa została powołana w sierpniu 1920 r., a jej program opierał się głównie na dążeniu środkami rewolucyjnymi do powołania niepodległego państwa, dającego wyraz narodowej tożsamości narodu ukraińskiego. W roku 1929 weszła formalnie w skład OUN, która powstała z połączenia trzech radykalnych grup nacjonalistycznych. Oprócz UOW w jej skład weszły Związek Nacjonalistycznej Młodzieży Ukraińskiej oraz Legia Ukraińskich Nacjonalistów. Celem OUN była walka z Polską, Rumunią oraz ZSRR w celu utworzenia niepodległej Ukrainy (w granicach - od Donu aż po Małopolskę), poprzez m.in. oderwanie od państwa polskiego województw: lwowskiego, tarnopolskiego i stanisławowskiego. Wskazane cele miała osiągnąć, prowadząc działalność terrorystyczną, dywersyjną, szkoleniową i propagandowo-oświatową (zob. L. Kulińska, Działalność terrorystyczna i sabotażowa nacjonalistycznych organizacji ukrainskich $w$ Polsce $w$ latach 1922-1939, Kraków 2009, s. 16). W okresie okupacji Wołynia i Małopolski Wschodniej przez III Rzeszę Niemiecką ukraińskie życie polityczne reprezentowane było w zasadzie wyłącznie przez OUN. Żadne z powojennych ukraińskich legalnych stronnictw politycznych nie podjęło działalności. W 1940 r. organizacja przeszła kryzys wewnętrzny, będący wynikiem buntu zwolenników Stepana Bandery przeciw Andrijowi Melnykowi, w rezultacie czego dalej działały niezależnie od siebie dwie OUN: OUN-Melnykowcy i OUN-Banderowcy (zob. W. Bonusiak, Małopolska Wschodnia pod rząami Trzeciej Rzeszy, op. cit., s. 122). Obradująca w lutym 1943 r. na III Konferencji OUN-Banderowcy określiła cele zadań organizacji jako walkę przeciw sowieckim partyzantom i Polakom oraz dążenie do utworzenie wolnej Ukrainy (zob. W. Bonusiak, Wołyń podczas II wojny światowej, op. cit., s. 430). Od kwietnia/ maja 1943 r. oddziały OUN-Banderowcy zaczęły używać nazwy Ukraińska Powstańcza Armia, wykorzystując popularność tej formacji.

Brak jest zgody co do okresu powołania UPA, jak i rozpoczęcia przez nią zaplanowanych centralnie działań. Dzień 14 października 1942 r., kiedy pierwsze oddziały UPA, uchodząc przed Niemcami z Polesia przeszły na Wołyń, jest przez część historyków traktowany jako data faktycznego powstania UPA. Sama nazwa 
pojawiła się w nazewnictwie banderowców dopiero 15 marca 1943 r., w miejsce dotychczas używanej Nacjonalistycznej Armii Podziemnej (lub Wojskowe Oddziały OUN); (zob. E. Prus, Atamania UPA. Tragedia kresów, Warszawa 1988, s. 17-19, 39). Programowo stojąc na stanowisku walki przeciwko wszystkim wrogom Ukrainy, faktycznie UPA skoncentrowała się na wojnie przeciw Polakom i partyzantce radzieckiej. Dążąc do usunięcia Polaków z Wołynia i Małopolski Wschodniej dopuszczano się mordów na tamtejszej ludności (zob. W. Bonusiak, Małopolska Wschodnia pod rzadami Trzeciej Rzeszy, op. cit., s. 127). Początkowo zabijano pojedyncze osoby, pod koniec 1942 r. mordy stały się coraz częstsze i obejmowały całe polskie rodziny. Jak wskazują historycy, był to początek zorganizowanej i planowanej akcji antypolskiej prowadzonej przez UPA. Według ich szacunków, w wyniku antypolskiej akcji ukraińskiej na Wołyniu tylko w 1943 r. zginęło 50 tys. osób (zob. W. Filar, Wołyń 1939-1944. Eksterminacja czy walki polsko-ukraińskie, Toruń 2003, s. 94; W. Siemaszko, E. Siemaszko, Ludobójstwo dokonane przez nacjonalistów ukraińskich, op. cit., s. 1045; W. Bonusiak, Wołyń podczas II wojny światowej, op. cit., s. 428-429). Od początku 1944 r. masowe mordy na Polakach zaczęly występować także w Małopolsce Wschodniej w województwach: tarnopolskim, stanisławowskim i lwowskim. Większość była dziełem oddziałów UPA przemieszczających się z terenu Wołynia. Ludobójstwo na większą skalę nastąpiło od marca 1944 r. Dokonywane było przez różne odłamy ukraińskich organizacji nacjonalistycznych: bulbowców, banderowców (OUN-Banderowcy), melnykowców (OUN-Melnykowcy), petlurowców, a także kozaków zbiegłych ze służby niemieckiej, partyzantów radzieckich, dezerterów z ukraińskiej policji czy zwyczajnych bandytów (zob. W. Bonusiak, Małopolska Wschodnia pod rzadami Trzeciej Rzeszy, op. cit., s. 216). W konsekwencji omawianych wydarzeń, według ustaleń historyków w Małopolsce Wschodniej zostało zamordowanych od 20-25 (zob. G. Hryciuk, Przemiany narodowościowe, op. cit., s. 315) do 30-40 tys. Polaków (zob. G. Motyka, Od rzezi wołyńskiej do akcji „Wisła”, op. cit., s. 447), a nawet liczbę polskich ofiar na tym terenie szacuje się na ok. 70 tys., z czego 20383 znane z nazwiska (zob. E. Siemaszko, Bilans zbrodni, „Biuletyn IPN” 2010, nr 7-8, s. 77-94). Od wiosny 1945 r. mordy na Polakach w Małopolsce Wschodniej stawały się rzadsze. Główną tego przyczyną było masowe wysiedlanie Polaków. Do końca 1945 r. wyjechało ok. 800 tys. Polaków (na terenie USRR pozostało 150-250 tys.). Ciężar działań antypolskich UPA przeniosła na tereny obecnej Polski (zob. G. Motyka, Ukraińska partyzantka, op. cit., s. 409). Z punktu widzenia art. 2a ustawy o IPN zbrodniczy charakter będą miały tylko te działania, które były motywowane ukraińskim nacjonalizmem i tym różnią się od innych zbrodni popełnianych na wskazanych terenach.

Zdaniem badaczy historii organizacja mordów, ich przebieg, zasięg terytorialny i rozmiary, propagowana przy tym ideologia nacjonalistyczna nawołująca do wyniszczenia Polaków jako grupy narodowościowej niezbicie świadczą, że była to zamierzona i zorganizowana akcja fizycznej eksterminacji ludności pol- 
skiej - w świetle konwencji w sprawie zapobiegania i karania zbrodni ludobójstwa z 1948 r. kwalifikowana jako ludobójstwo, połączona z niszczeniem śladów kultury polskiej - domostw, kościołów i innych zabytków (zob. E. Siemaszko, Od walk do ludobójstwa, http://www.rp.pl/artykul/161001-Od-walk-do-ludobojstwa.html). Wskazuje się również, że termin ludobójstwo dobrze oddaje kwalifikację prawną ówczesnych wydarzeń, gdyż Polacy ginęli tylko z powodu swojej narodowości (zob. G. Motyka, Ukrainska partyzantka, op. cit., s. 413).

Z powyższych ustaleń wynika, że realizacja założeń ideologii ukraińskiego nacjonalizmu doprowadziła na terenach Wołynia i Małopolski Wschodniej do czystek etnicznych, które mają charakter zbrodni ludobójstwa. Ukraińskim nacjonalistą w rozumieniu art. 2a ustawy o IPN będzie zatem osoba identyfikująca się z ideologią ukraińskiego nacjonalizmu oraz podejmująca działania nią motywowane. Zbrodniami ukraińskich nacjonalistów w kontekście kwestionowanego przepisu będą natomiast czyny popełnione w latach 1925-1950, polegające na stosowaniu przemocy, terroru lub innych form naruszania praw człowieka wobec jednostek lub grup ludności, jak również udział w eksterminacji ludności żydowskiej oraz ludobójstwie na obywatelach II Rzeczypospolitej na terenach Wołynia i Małopolski Wschodniej, które były motywowane ideologią ukraińskiego nacjonalizmu. Ustawodawca w art. 55 ustawy o IPN reguluje z kolei odpowiedzialność karną za publiczne i wbrew faktom negowanie tych zbrodni. Używając pojęcia zbrodni dokonanych przez ukraińskich nacjonalistów, jest konsekwentny w stosowaniu tego nazewnictwa, na co wskazuje uchwała Sejmu Rzeczypospolitej Polskiej z dnia 22 lipca 2016 r. w sprawie oddania hołdu ofiarom ludobójstwa dokonanego przez nacjonalistów ukraińskich na obywatelach II Rzeczypospolitej Polskiej w latach 1943-1945 (M. P. poz. 726).

Biorąc pod uwagę powyższe ustalenia, należy uznać, że niedookreśloność i nieostrość zaskarżonego wyrażenia „ukraiński nacjonalista” nie osiąga takiego stopnia, który należałoby uznać za niezgodny z zasadą określoności przepisów wyrażoną w art. 42 ust. 1 i art. 2 Konstytucji. Znaczenie zaskarżonego wyrażenia może być ustalone przede wszystkim przez odwołanie się do znaczeń, jakie ma ono w ujęciu historycznym.

3. Mając powyższe na uwadze, Sejm wnosi jak na wstępie.

\section{Bibliografia}

Antypolska akcja nacjonalistów ukraińskich w Małopolsce Wschodniej w świetle dokumentów Rady Głównej Opiekuńczej 1943-1944, wstęp i oprac. L. Kulińska, A. Roliński, Kraków 2003.

Banaszak B., Konstytucja Rzeczypospolitej Polskiej. Komentarz, Warszawa 2012.

Bonusiak W., Małopolska Wschodnia pod rządami Trzeciej Rzeszy, Rzeszów 1990. 
Bonusiak W., Wołyń podczas II wojny światowej [w:] Historia i dziedzictwo regionów w Europie Środkowo-Wschodniej w XIX i XX w., red. M. Stolarczyk, A. Kawalec, J. Kuźnicki, Rzeszów 2011.

Ćwiąkalski Z., O niektórych pojęciach związanych z wymiarem kary, „Nowe Prawo” 1989, nr 4.

Dąbkowski T., Ukrainski ruch narodowy 1912-1923, Warszawa 1985.

Dębski R., Pozaustawowe znamiona przestępstwa. O ustawowym charakterze norm prawa karnego i znamionach typu czynu zabronionego nie określonych w ustawie, Łódź 1995.

Filar W., Wołyń 1939-1944. Eksterminacja czy walki polsko-ukraińskie, Toruń 2003.

Filar M., Berent M., Opinia prawna w przedmiocie poselskiego projektu ustawy o zmianie ustawy I Instytucie Pamięci Narodowej - Komisji Ścigania Zbrodni przeciwko Narodowi Polskiemu oraz ustawy - Kodeks karny z 4.2.2014 r. (druk 1958), http://orka.sejm. gov.pl/rexdomk7.nsf/Opdodr?OpenPage\&nr=1958.

Gardocka T., Czy w polskim prawie karnym potrzebny jest kontratyp sztuki?, „Palestra” 2015, nr 1-2.

Garlicki L., Wojtyczek K., Komentarz do art. 31 [w:] Konstytucja Rzeczypospolitej Polskiej. Komentarz, t. II, red. L. Garlicki, M. Zubik, Warszawa 2016.

Garlicki L., Zubik M., Komentarz do art. 73 [w:] Konstytucja Rzeczypospolitej Polskiej. Komentarz, t. II, red. L. Garlicki, M. Zubik, Warszawa 2016.

Giezek J., O sankcjach alternatywnych oraz możliwości wyboru rodzaju wymierzanej kary, „Palestra” 2015, nr 7-8.

Haliczer J., Małopolska [w:] Encyklopedja nauk politycznych (zagadnienia społeczne, polityczne i gospodarcze), t. III, red. E.J. Reyman, Warszawa 1938.

Hibel K., Od „Małopolski Wschodniej” do „Ukrainy Zachodniej”. Geneza, rozwój oraz zakres funkcjonowania w języku polskim nazw geograficznych odnoszących się do „Galicji Wschodniej” w latach 1918-1939, „Slavia Orientalis” 2012, t. LXI, nr 4.

Hryciuk G., Przemiany narodowościowe i ludnościowe w Galicji Wschodniej i na Wołyniu w latach 1931-1948, Toruń 2005.

Jabłoński M., Wolności z art. 73 Konstytucji RP [w:] Prawa i wolności obywatelskie w Konstytucji RP, red. B. Banaszak, A. Preisner, Warszawa 2002.

Janisławski A., Konopka P., Zagadnienie penalizacji „kłamstwa oświęcimskiego”, „Palestra” 2009, nr 1-2.

Jarosz-Żukowska S., Żukowski Ł., Wolność badań naukowych i nauczania [w:] Realizacja i ochrona konstytucyjnych wolności i praw jednostki w polskim porządku prawnym, red. M. Jabłoński, Wrocław 2014.

Konstytucja Rzeczypospolitej Polskiej. Komentarz, t. I, red. L. Garlicki, M. Zubik, Warszawa 2016.

Korybski A., Leszczyński L., Pieniążek A., Wstęp do prawoznawstwa, Lublin 2003.

Kościół Rzymskokatolicki i Polacy w Małopolsce Wschodniej podczas wojny ukraińsko-polskiej 1918-1939. Źródła, oprac., wstęp, przypisy, indeksy i wybór fotografii J. Wołczański, t. I, II, Lwów-Kraków 2012.

Kotliński T.J., Towarzystwo Galicyjskich Kandydatów Notarialnych Wschodniej Małopolski we Lwowie (1889-1939), „Rejent” 2009, nr 3. 
Kulesza W., Zniesławienie i zniewaga (Ochrona czci i godności osobistej człowieka w polskim prawie karnym - Zagadnienia podstawowe), Warszawa 1984.

Kulińska L., Działalność terrorystyczna i sabotażowa nacjonalistycznych organizacji ukraińskich $w$ Polsce w latach 1922-1939, Kraków 2009.

Kumaniecki K.W., Wasiutyński B., Panejko J., Polskie prawo administracyjne w zarysie, Kraków 1929.

Kwestia ukraińska i eksterminacja ludności polskiej w Małopolsce Wschodniej w świetle dokumentów Polskiego Państwa Podziemnego 1942-1944, wstęp i oprac. L. Kulińska, A. Roliński, Kraków 2004.

Makarewicz J., Kodeks karny z komentarzem, Lwów 1938.

Makowski W., Kodeks karny, Warszawa 1933.

Małopolska Wschodnia [w:] Encyklopedja podręczna prawa publicznego (konstytucyjnego, administracyjnego i międzynarodowego), t. I, red. Z. Cybichowski, Warszawa 1930.

Małopolska Wschodnia. Nasza historia, nasza pamięć, cz. 4, Kraków 2014.

"Mały Rocznik Statystyczny 1939".

Mazur G., Skwara J., Węgierski J., Kronika 2350 dni wojny i okupacji Lwowa 1 IX 1939 5 II 1946, Katowice 2007.

Morawski L., Zasady wykładni prawa, Warszawa 2014.

Motyka G., Libionka D., Antypolska akcja OUN-UPA 1943-1944. Fakty i interpretacje, seria „Konferencje IPN” t. 4, Warszawa 2002.

Motyka G., Od rzezi wołyńskiej do akcji „Wisła”. Konflikt polsko-ukraiński 1943-1947, Kraków 2011.

Motyka G., Postawy wobec konfliktu polsko-ukraińskiego w latach 1939-1953 w zależności od przynależności etnicznej, państwowej i religijnej [w:] Tygiel narodów. Stosunki społeczne i etniczne na dawnych ziemiach wschodnich Rzeczypospolitej, red. K. Jasiewicz, Warszawa/Londyn 2002.

Motyka G., Ukrainska partyzantka 1942-1960, Warszawa 2006.

Peiper L., Kodeks karny i prawo o wykroczeniach, Kraków 1933.

Piechowiak M., Dobro wspólne jako fundament polskiego porządku konstytucyjnego, Warszawa 2012.

Podraza A., Europa. Galicja. Regiony. Pisma historyczne, Kraków 2006.

Prus E., Atamania UPA. Tragedia kresów, Warszawa 1988.

Prus-Faszczewski T., Małopolska Wschodnia a zagadnienie obronności państwa, Warszawa 1939.

Sał J., Galicja Wschodnia [w:] Encyklopedia historii Polski. Dzieje polityczne, t. 1, Warszawa 1994.

Siemaszko E., Bilans zbrodni, „Biuletyn IPN” 2010, nr 7-8.

Siemaszko E., Od walk do ludobójstwa, http://www.rp.pl/artykul/161001-Od-walk-do-ludobojstwa.html.

Siemaszko W., Siemaszko E., Ludobójstwo dokonane przez nacjonalistów ukraińskich na ludności polskiej Wolynia 1939-1945, t. I i II, Warszawa 2000.

Słownik języka polskiego, t. II, red. M. Szymczak, Warszawa 1995. 
Sokolewicz W., Uwaga 6 do art. 1 [w:] Konstytucja Rzeczypospolitej Polskiej. Komentarz, t. V, red. L. Garlicki, Warszawa 2007.

Sokolewicz W., Zubik M., Komentarz do art. 2 [w:] Konstytucja Rzeczypospolitej Polskiej. Komentarz, t. I, red. L. Garlicki, M. Zubik, Warszawa 2016.

Starck C., Wolność badań naukowych i jej granice, „Przegląd Sejmowy” 2007, nr 3.

Warylewski. J., Zasady techniki prawodawczej. Komentarz do rozporządzenia, Warszawa 2003.

Wąsek A., Kodeks karny. Komentarz, t. I, Gdańsk 1999.

Wilk L., Komentarz do art. 130 [w:] Prawo farmaceutyczne. Komentarz, red. L. Ogiegło, Warszawa 2015.

Wysocki R., Organizacja Ukraińskich Nacjonalistów w Polsce w latach 1929-1939, Lublin 2003.

Zamoyski G., Zmiany podziałów administracyjnych na terenie województw południowych w latach 1918-1939 [w:] Historia. Archiwistyka. Ludzie. Księga pamiątkowa w pięćdziesiata rocznice powołania Archiwum Państwowego w Rzeszowie, Warszawa-Rzeszów 2000. 